\title{
Izbori i imenovanja biskupâ u Hercegovini u doba austro-ugarske vladavine (1878. - 1918.) na primjeru biskupa fra Alojzija Mišića (1912.)*
}

\author{
Petar VRankić \\ Kath.-Theologische Fakultät der \\ Universität Augsburg \\ Privatadresse: \\ Königsberger Str. 14 \\ D - 86381 Krumbach \\ E-pošta:vrankic@t-online.de
}

UDK: 262.1 (497.6 Hercegovina)"1878/1918"

929 Mišić A.

Izvorni znanstveni rad

Primljeno: 25. lipnja 2018

Prihvaćeno: 16. srpnja 2018.

\section{Sažetak}

U ovom drugom radu o izboru biskupâ u Hercegovini u doba austro-ugarske vladavine (1878. - 1918.), koji na neki način nastavlja tematiku, koja je obrađena u prvom prilogu, ${ }^{1}$ prikazuje se vrlo napeta i otporna borba oko izbora drugoga biskupa u

* Rad se zasniva na konzultaciji Kućnoga, dvorskog i državnog arhiva u Beču, Arhiva BiH u Sarajevu, Vatikanskoga tajnog arhiva i Arhiva Svetoga Zbora za širenje vjere (Propaganda Fide) u Rimu, Arhiva Nadbiskupskoga ordinarijata u Sarajevu i Arhiva Biskupskoga ordinarijata u Mostaru. Potraživana arhivska građa iz Arhiva Franjevačke provincije u Mostaru nije stigla do prijeloma ovoga teksta. Najiskrenija hvala dobroti svih onih osoba koje su pomogle pri sakupljanju potrebne arhivske građe i literature.

1 Usp. Petar Vrankić, "Izbori i imenovanja biskupâ u Hercegovini u doba austro-ugarske vladavine (1878.-1918.) na primjeru biskupa Paškala Buconjića", u: Hercegovina, 2, Mostar, 2016., str. 109-140. 
Hercegovini u doba austro-ugarske vladavine, fra Alojzija Mišića. Poslije kratkoga prikaza povijesno-pravnoga konteksta Katoličke Crkve u Hercegovini u doba austro-ugarske vladavine prelazi se u prvom poglavlju ponajprije na traženje biskupa cum iure successionis (pomoćnoga biskupa s pravom nasljedstva, tj. koadjutora), starom i onemoćalom biskupu Buconjiću u Mostaru. Zainteresirane strane, koje uzimaju dijela u ovom vrlo napetom natjecanju jesu: Zemaljska vlada u Sarajevu, Zajedničko ministarstvo financija u Beču, nadbiskup Josip Stadler kao vrhbosanski metropolit, biskup Buconjić u Mostaru, provincijal Bosne Srebrene, fra Alojzije Mišić i provincijal Hercegovačke franjevačke provincije, fra Luka Begić te Sveta Stolica u Rimu (Vatikan). Ovo natjecanje, koje poprima oblike međusobne borbe, uključujući, s poneke strane i omalovažavanje protivnika po $\mathrm{BiH}$, Beču i Rimu, traje od kraja siječnja do početka prosinca 1910. Kako Sveta Stolica u Rimu nije bila uvjerena o prikladnosti jedinoga kandidata, kojega je protežirala Zemaljska vlada u Sarajevu, provincijala Mišića, stvar je mirovala do smrti biskupa Buconjića 8. prosinca 1910.

Poslije smrti biskupa Buconjića, prelazi se u drugo poluvrijeme međusobnoga natjecanja, koje je obrađeno u trećem poglavlju, u kojemu se pojavljuju osim starih i novi akteri i kandidati. Prije svega nastupa nadbiskup Stadler kao metropolit i imenuje privremene upravitelje in spiritualibus (u duhovnim stvarima) i in materialibus (u materijalnim dobrima) biskupije Mostarskoduvanjske. Time je bilo osigurano minimalno funkcioniranje biskupijâ. Nakon toga on je poslao svoju listu kandidata kako Zemaljskoj vladi, tako i Svetoj Stolici. Stadlerova lista kandidata nije mogla proći kod Vlade, jer je nadbiskup Stadler već godinama javno kritizirao Vladu i njezine postupke prema njemu, njegovim institucijama, svećenicima i Katoličkoj Crkvi u BiH uopće. U Rimu su Stadlerovi kandidati nailazili djelomično na razumijevanje i simpatiju, posebno pomoćni biskup dr. Ivan Šarić. No, Zemaljska je vlada i dalje samouvjereno stajala iza svoga kandidata, bosanskoga provincijala Mišića, ne samo kao prikladna čovjeka Crkve, nego i kao čovjeka, subjekta njezina povjerenja i kućnoga prijatelja Vladinih službenika, s kojim se rado savjetovala. Stoga Vlada argumentira smiješnim i neobjektivnim prigovorima kada se radi o kandidatima koji joj nisu po volji ili su prava konkurencija za Mišića. Tako među kandidatima, koje je Rim snažno podupirao i koje je biskup Buconjić bio predložio, bio je i fra Frano Lulić iz Makarske. Njega je Vlada kao Dalmatinca prikazala neprikladnim, jer ne će razumjeti mentalitet puka u Hercegovini, čovjeka koji je bio rođen tri puta bliže 
Hercegovini nego provincijal Mišić. Tako se manifestira Vladina politika kao merum absurdum in se!

Novost u ustajale pregovore unosi, iz političkih i osobnih uvjerenja, predsjednik Bosansko-hercegovačkoga sabora, dr. Nikola Mandić, koji nije bio dovoljno uvjeren u prikladnost provincijala Mišića te je tražio imenovanje jednoga od hercegovačkih franjevaca, ideja koju je čak bilo prihvatilo i Ministarstvo u Beču. Premda je Vlada u Sarajevu pokušala ne zamjeriti se Ministarstvu u Beču i djelomično prihvatiti njegove prijedloge, ostala je i dalje duboko uvjerena u ispravnost svoga stajališta: provincijal Mišić je jedini prikladan kandidat. Kao što je Zemaljska vlada bila uvjerena da je Mišić bio jedini prikladan kandidat za biskupa u Mostaru, tako je istovremeno i Sveta Stolica, sve do početka veljače 1912., postojano držala provincijala Mišića posve neprikladnim za biskupa u Mostaru. Kada se pronio glas da je kandidat Lulić teško obolio, i kada je spor oko biskupskoga imenovanja u Mostaru mogao dovesti do političke napetosti između Beča i Svete Stolice, Državno tajništvo Svete Stolice i sam papa Pio X. odlučili su, početkom veljače 1912., prihvatiti kandidaturu fra Alojzija Mišića i utrti mu put za biskupsko imenovanje u Mostaru.

Ovo se istraživanje temelji na arhivskim vrelima. Nejasnoću, ponekada i pravu proturječnost o imenima kandidata, tijeku pregovora te donekle premalo pohvalne riječi o hercegovačkim franjevcima donosi Chronika biskupije i osobni Životopis, pisani post factum od biskupa Mišića, sačuvani u Arhivu Biskupskoga ordinarijata u Mostaru.

Ključne riječi: Hercegovina; Mostarsko-duvanjska biskupija; Trebinjsko-mrkanska biskupija; Zemaljska vlada; Zajedničko ministarstvo financija; Austro-Ugarska; bosanski franjevci; hercegovački franjevci; fra Paškal Buconjić; fra Alojzije Mišić; fra Frano Lulić; nadbiskup Stadler; Dom Pierre Bastien. 


\section{Povijesno-pravni kontekst Katoličke Crkve u Hercegovini 1910. - 1912. godine}

Izbor biskupa u Katoličkoj Crkvi, kao što smo to već prije naglasili, ${ }^{2}$ bio je i ostao vrlo složen crkveno-pravni, a u nekim zemljama čak i državno-crkveno-pravni proces. Od zaposjednuća Bosne i Hercegovine 1878. godine i potpisivanja Konvencije između Austro-Ugarske i Svete Stolice, 8. lipnja 1881. u Rimu, ${ }^{3}$ u Katoličkoj Crkvi u Hercegovini do 1918. godine došlo je samo do dva biskupska imenovanja. ${ }^{4} \mathrm{Ov}-$ dje ćemo obraditi drugo biskupsko imenovanje u Hercegovini. Smrt mostarskoga biskupa i apostolskoga upravitelja Trebinjsko-mrkanske biskupije, fra Paškala Buconjića, nije došla iznenada za njegove suradnike, posebno za Hercegovačku franjevačku provinciju. Biskup Buconjić, premda nije bio prestar, pobolijevao je sve češće posljednjih godina svoga života. Ipak je njegova smrt 8. prosinca 1910. zatekla Crkvu u Hercegovini nedovoljno pripremljenu za biskupsku promjenu, odnosno za novo biskupsko imenovanje. Franjevačka provincija Marijina Uznesenja, kao glavni izvor redovničkih i svećeničkih zva-

2 U ovome prilogu slijedi se već uhodana shema koja je nastala u prvom prilogu o izboru i imenovanju biskupa u $\mathrm{BiH}$ u doba austro-ugarske vladavine (1878. 1918.). Usp. P. Vrankić, "Izbori i imenovanja biskupâ u Hercegovini", str. 111.

3 Konvencija (Ugovor) između Svete Stolice i Austro-Ugarske od 8. lipnja 1881. ostala je do danas dokument historijskih dimenzija za Katoličku Crkvu u BiH. Potpisao ju je kardinal državni tajnik, Lodovico Jacobini i austro-ugarski veleposlanik pri Svetoj Stolici, grof Ludwig Paar. Konvencija je bila, kao i svaki drugi međudržavni i međunarodni ugovor, kompromisno rješenje dviju zainteresiranih strana. I osim davanja povlastica Caru od Svete Stolice, da može imenovati nadbiskupa, biskupe i kanonike u $\mathrm{BiH}$, na isti način kao u cijeloj Carevini, Konvencija je bila velik dobitak za Katoličku Crkvu u BiH. Ona je služila i još uvijek služi kao predložak za sve važnije crkveno-državne ugovore s obzirom na Katoličku Crkvu u BiH. Usp. HHStA Wien, Adm. Reg. F27/40. Nr. 84; Angelo Mercati (prir.), Raccolta di concordati su materie ecclesiastiche tra la Santa Sede e le autorità civili 1098-1914, I., Tipografia poliglotta vaticana, Città del Vaticano, 1954., str. 1014-1015; BERISLAV GAVRANOVIĆ, Uspostava redovite katoličke hijerarhije u Bosni i Hercegovini 1881. godine. Prilog političkoj historiji Austro-Ugarske Monarhije na Balkanu, Beograd, 1935., str. 196-202; Đuro KoKša, "Uspostava redovite hijerarhije u BiH 1881.", u: Petar Baвıć - Mato Zovkić (prir.), Katolička Crkva u Bosni i Hercegovini u XIX i XX stoljeću, Studia Vrhbosnensia, I., Vrhbosanska visoka teološka škola, Sarajevo, 1986., str. 21-60; Petar VRankić, Religion und Politik in Bosnien und der Herzegowina (1878-1918), Ferdinand Schöningh, Paderborn, 1998., str. 469472; P. VRAnkić, "Izbori i imenovanja biskupâ u Hercegovini", str. 111.

To su bili biskup Buconjić 1881. i biskup Mišić 1912. godine. 
nja i eventualnih kandidata za novoga biskupa u Hercegovini, nalazila se još uvijek u sporoj uzlaznoj putanji rasta i nužne unutarnje izgradnje i učvršćivanja, koje je samo postupno moglo uslijediti poslije zaposjednuća $\mathrm{BiH}$ od Austro-Ugarske. Radilo se prije svega o uzdizanju Hercegovačke kustodije na rang Provincije 1892. godine. ${ }^{5}$ Već od 1880. primala je Kustodija od Zemaljske vlade po 1000 forinti godišnje potpore za samostane na Humcu i Širokom Brijegu. Osim toga, Vlada je od 1880. davala potporu od 750 forinti za studente u Innsbrucku, potporu Kustodu od 500 forinti i godišnju potporu svakom župniku od 100 forinti. Tako je godišnja potpora 1880. Franjevačkoj kustodiji u Hercegovini iznosila 6450 forinti. ${ }^{6}$ Premda su Kustodija, i od 1892. Provincija, u nastupajućem razdoblju, spomenutom potporom Vlade, milodarima i stalnim prošnjama po Monarhiji, napravile vidan napredak u podizanju internih i vanjskih redovničko-crkvenih i materijalnih struktura, proširenjem ili gradnjom samostana u Mostaru (1890. - 1894.) i Humcu (1895.), otvaranjem niže gimnazije na Širokom Brijegu (1889.) i bogoslovije u Mostaru (1895.), gradnjom nove crkve na Sirokom Brijegu (1905. - 1911.) ${ }^{7}$ te brojnih crkava i župnih kuća kao i odgojem i školovanjem zavidna broja redovnika i svećenika, nisu istovremeno u tom kratkom razdoblju uspjele odgojiti i oformiti veći broj intelektualno sposobnijih i zapaženijih redovnika, koji bi mogli djelovati na vodećim crkvenim mjestima. Istina, jedna zdrava kombinacija redovničkih službi (odgojitelj mladeži i novaka, gimnazijski učitelj i bogoslovijski profesor) s pastoralnim iskustvom (kapelan, župnik i vjeroučitelj, biskupski tajnik ili čak generalni vikar) pružali su mladom i sposobnom hercegovačkom franjevcu zavidnu redovničku i svećeničku formaciju i izobrazbu te jedinstvenu ukorijenjenost $\mathrm{u}$ vjerničkom puku i $\mathrm{u}$ hrvatskome narodu u Hercegovini. No, to nije bilo dovoljno, kako su to znali i primjećivali već desetljećima vodeći oci Kustodije i Provincije. Poslije bolne ali i uspješne diobe od Bosne Srebrene, hercegovački franjevci ostali su isključivo povezani s talijanskim samostanima, koji su bili istovremeno i njihovi odgojni centri, daleko od same talijanske sveučilišne i intelektualne visine, koji se opet nisu mogli us-

5 P. VRankić, Religion und Politik, str. 570-577; Bazilije S. PandžIć, Hercegovački franjevci. Sedam stoljeća s narodom, Mostar - Zagreb, 2001., str. 143-144.

6 Dopis Zemaljskoga poglavara, generala Würtemberga, Zajedničkom ministarstvu financija u Beču, 30. svibnja 1880. ABH Sarajevo, LR Präs. BH, 7447/1880; P. VRANKIć, Religion und Politik, str. 573.

7 B. S. PANDžIĆ, Hercegovački franjevci, str. 154. 
porediti s intelektualnom i pedagoškom razinom učilišta i sveučilišta Dvojne Monarhije ili Njemačkoga Carstva. Zaposjednućem BiH od Austro-Ugarske otvorila se mogućnost i hercegovačkim franjevcima u daljoj ili bližoj budućnosti da i oni mogu pohađati teološka učilišta i sveučilišta Dvojne Monarhije, posebno u Innsbrucku. No, zato je bila potrebna završena i priznata gimnazija, koju je Provincija s mukom uspostavila s pet razreda na Širokom Brijegu i s tri godine na Humcu. ${ }^{8}$ Tek tada su bila otvorena vrata Provinciji za Vladinu financijsku potporu u visini od 4080 forinti za smještaj hercegovačkih studenata u isusovačkome kolegiju Canisianum i za studij na Sveučilištu u Innsbrucku. No, ovu potporu Starješinstvo je radije htjelo namijeniti za dogradnju i studij na tek otvorenoj Bogosloviji u Mostaru, što je dovelo do napetosti sa Zemaljskom vladom u Sarajevu. Hercegovački franjevci, u usporedbi sa svojom subraćom iz Bosne Srebrene, bili su odlučniji nositelji hrvatske prosvjete, pismenosti, izdavačke djelatnosti i kulturnoga uzdizanja katolika Hrvata u Hercegovini. Ova njihova politička, kulturna i narodna djelatnost, premda su i oni istodobno ritualno ispovijedali svoju vjernost Monarhiji, Caru i Dinastiji, zvučala je previše austrofilski, trijalistički i hrvatski te nije nailazila na prihvaćanje kod prougarski orijentirane Zemaljske vlade u Sarajevu. Stoga je moguće da je i ovo bio dovoljan razlog da se sustavno izbjegavaju hercegovački franjevci (1910. - 1912.) prigodom traženja kandidata za upražnjenu biskupsku stolicu u Mostaru.

\section{Traženje koadjutora za biskupa Buconjića}

\subsection{Kandidati provincijala Mišića i Zemaljske vlade u Sarajevu}

Biskupu Buconjiću posljednjih godina njegova biskupovanja nedostajala je sve više snaga i koncentracija za mnoga goruća pitanja Crkve u Hercegovini. Premda je nova biskupska rezidencija bila dogotovljena, on se odupirao preseljenju, te je životario u Vukodolu iznad Mostara. Njegovi neposredni suradnici i savjetnici, prvenstveno Radoslav Glavaš, ${ }^{9}$ u strahu da ne izgube naklonost i povlašteni položaj kod biskupa, podržavali su ga u neizvjesnosti i neobaviještenosti i time ga držali pod kontrolom i ovisnošću. Tako se u Mostaru nisu mogli očekivati neki odlučniji koraci u vođenju hercegovačkih bi-

8 Isto, str. 153.

9 Fra Radoslav Glavaš (Drinovci, 1867. - Humac, 1913.). Usp. RoBERT Jolić, Leksikon hercegovačkih franjevaca, Mostar, 2011., str. 147-148. 
skupija i traženju rješenja za nastale probleme i pitanja. ${ }^{10}$ No to su primijetili drugi, među njima i Buconjićev metropolit i sarajevski nadbiskup Josip Stadler. Stoga je on, 28. siječnja 1910., u audijenciji kod Zajedničkoga ministra financija i upravitelja $\mathrm{BiH}$, baruna $\mathrm{Bu}$ riána, ${ }^{11}$ predložio imenovanje sarajevskoga pomoćnog biskupa Ivana Šarića ${ }^{12}$ kao biskupa koadjutora s pravom nasljedstva (episcopus auxiliaris cum iure successionis) u Mostaru. ${ }^{13}$ Kanonik Šarić, premda čovjek najdubljega povjerenja nadbiskupa Stadlera, bio je u početku logičan kandidat Zemaljske vlade u Sarajevu za predviđeno mjesto. ${ }^{14}$ No, ministar Burián, uvjereni madžarski nacionalist, nije rado vidio na biskupskim stolicama ili drugim vodećim crkvenim položajima,

10 U spomenici, objavljenoj prigodom tridesetogodišnjice biskupovanja biskupa Buconjića 1910., nema nijedne riječi o eventualnim slabostima i propustima na veliko hvaljenoga biskupa Buconjića. Usp. Radoslav Glavaš, Biskup o. Paškal Buconjić prigodom tridesetogodišnjice biskupovanja 1880-1910., Mostar, 1910.

11 Barun István (Stjepan) Burián von Rajecz (od 1918. grof) (Stampfen kod Bratislave, 1851. - Beč, 1922.), bio je Zajednički ministar financija Austro-Ugarske Monarhije, upravitelj BiH (1903. - 1912.) te time glavni politički, financijski i vjerski upravitelj zaposjednutih zemalja. Zastupao je u BiH uvjereno, ako je imao prostora za to, antihrvatsku, antimuslimansku, prosrpsku te istovremeno veleugarsku politiku Pešte.

12 Ivan Evanđelist Šarić (Dolac kod Travnika, 1871. - Madrid, 1960.), vrhbosanski svećenik i kanonik, doktor teologije Zagrebačkoga sveučilišta (1898.), pomoćni biskup vrhbosanski (1908. - 1918.), kaptolski vikar Vrhbosanske nadbiskupije (1918. - 1922.), vrhbosanski nadbiskup (1922. - 1960.), pisac, pjesnik i prevoditelj Svetoga Pisma, osnivač brojnih župa, pobornik katoličkoga tiska i Katoličke akcije. Zbog prisne i za Crkvu nepoželjne suradnje s vlastima NDH od 1941. do 1945. napustio je 1945. nadbiskupiju i živio od 1945. do 1960. godine u Austriji, Švicarskoj i Španjolskoj, u izbjeglištvu, sklanjajući se pred komunističkom odmazdom i suđenjem. Umro je u Madridu, 16. srpnja 1960., opremljen sakramentima umirućih, koje mu je najvjerojatnije podijelio španjolski franjevac Miguel Oltra Hernández (1911. - 1982.).

Njegovi posmrtni ostatci iz Madrida preneseni su i pokopani 27. travnja 1997. u kripti crkve sv. Josipa na Marindvoru u Sarajevu, koju je kao nadbiskup dao izgraditi. Više u: AnĐelko Barun, Svjedoci i učitelji, Sarajevo - Zagreb, 2003., str. 340-341; PAvo JuRIšIć (prir.), Ivan Šarić vrhbosanski nadbiskup (Studia Vrhbosnensia, XIII.), Sarajevo, 2007. Usp.: https://www.vecernji.ba/nadbiskup-ivan-saric-423634 - www.vecernji.ba (11. 6. 2018.).

13 Dopis pročelnika odsjeka (Sektionschef) u Zajedničkom ministarstvu financija Thalloczya doglavniku (Ziviladlatus) Zemaljske vlade u Sarajevu, barunu Benku 6. veljače 1910. ABH Sarajevo, GFM Präs. BH, 95/1910. Usp. P. VRANKIĆ, Religion und Politik, str. 513.

14 Isto, str. 513. 
koje je vlada kontrolirala i financirala, svećenike koji su bili hrvatski orijentirani ili koji nisu studirali u Madžarskoj ili barem u Monarhiji. Istovremeno nadbiskup Stadler, donekle neshvatljivo u ovoj situaciji, obrazlaže nediplomatski u Beču svoj prijedlog jednostranom tvrdnjom da među hercegovačkim franjevcima nema prikladna kandidata. ${ }^{15}$ Ministar Burián mogao se samo radovati ovoj neopreznoj izjavi nadbiskupa Stadlera i stoga daje nalog Zemaljskoj vladi u Sarajevu da potraži među bosanskim franjevcima prikladnu osobu za pomoćnoga biskupa u Mostaru, ukoliko se takva osoba ne može naći među hercegovačkim franjevcima. ${ }^{16}$ Vrlo utjecajni visoki Vladini službenici u Sarajevu: Isidor Benko, ${ }^{17}$ Karl Pittner, ${ }^{18}$ Adalbert Shek ${ }^{19} \mathrm{i}$ Georg Treščec, ${ }^{20}$ znajući vrlo dobro koga ministar Burián u Beču želi i kako mu se može ugoditi, kreću na posao i obraćaju se provincijalu Bosne Srebrene, fra Alojziju Mišiću, ${ }^{21}$ nekadašnjem ugarskom (ostro-

15 Isto.

16 Isto.

17 Isidor Benko, barun Bojnički, (Prag, 1846. - Zagreb, 1925.), kotarski predstojnik u Nevesinju, okružni predstojnik u Mostaru, civilni adlatus (zemaljski doglavar) u Bosni i Hercegovini (1904. - 1912.), guverner Zemaljske banke u Sarajevu (1912.-1918.).

18 Karl Pittner, barun, pročelnik administrativnoga (upravnoga) odjela Zemaljske vlade $\mathrm{BiH}$.

19 Adalbert Shek, pl. Vugrovečki (Vugrovec pokraj Zagreba, 1851. - Zagreb, 1933.), pročelnik pravosudnoga odjela Zemaljske vlade $\mathrm{BiH}$ (1907. - 1913.).

20 Georg Treščec bio je dvorski savjetnik i dugogodišnji pročelnik odjela za bogoštovlje i nastavu u Zemaljskoj vladi u Sarajevu. Umirovljen u jesen 1910. Usp. Dopis Treščeca caru Franji Josipu 15. listopada 1910. ABH, GFM Präs. BH, 1694/1910; Roвın Океу, Timing Balkan Nationalism. The Habsburg "Civilizing Mission" in Bosnia, 1878-1914, Oxford University Press, Oxford, 2007., str. 302, n. 47.

21 Fra Alojzije Stjepan Mišić (Bosanska Gradiška, 10. studenog 1859. - Mostar, 26. ožujka 1942.) bio je ugledan bosanski franjevac, mostarsko-duvanjski biskup i apostolski upravitelj Trebinjsko-mrkanske biskupije od 1912. do 1942. U Franjevački red stupio je 1874. godine, filozofsko-teološke studije započeo je u samostanu Guča Gora i nastavio u Nadbiskupskome sjemeništu u Ostrogonu, u Ugarskoj. Osobno nije bio zadojen antiugarskim duhom, nije dijelio protumađarsko raspoloženje drugih bosanskih studenata-klerika u Ostrogonu i nije se pridružio njihovu bijegu u Bosnu 1880. godine. Time je počeo vrlo rano kotirati kao filougarski orijentirani franjevac. U Ostrogonu je završio studije i bio zaređen za svećenika 7. srpnja 1882. Službovao je kao vjeroučitelj u Sarajevu, biskupski tajnik i generalni vikar u Banjoj Luci, gvardijan na Petrićevcu, župnik u Bihaću, predstojnik Franjevačkoga kolegija u Visokom (1907. - 1909.), kustod (1907. - 1909.) i provincijal (1909. - 1912.) Bosne Sre- 
gonskom) studentu i osobi od povjerenja kod većinski promadžarski orijentiranih članova Zemaljske vlade u Sarajevu. Po usmenoj želji pročelnika odjela za bogoštovlje u Zemaljskoj vladi, Georga Treščeca, Mišić je trebao predložiti prikladne kandidate iz Hercegovačke provincije i iz provincije Bosne Srebrene za pomoćnoga biskupa u Mostaru. ${ }^{22} \mathrm{U}$ vrlo kratkom roku on sastavlja listu hercegovačkih i

brene. Mostarsko-duvanjskim biskupom imenovao ga je car Franjo Josip 14. veljače 1912. Za biskupsko geslo, poslije ređenja u Rimu, uzeo je: Caritate et amore omnia vincuntur (Milosrđem i ljubavlju sve se pobjeđuje). Na dužnosti biskupa ostao je do smrti. Nakon uspostave NDH nije se odmah dobro snašao u novonastalome političkom vrtlogu. Svojom biskupskom okružnicom od 9. svibnja 1941. pozdravio je proglašenje $\mathrm{NDH}$ i istovremeno proglasio da je poglavnik dr. Ante Pavelić "uzor kršćanin katolik". Usp. "Poslanica biskupa Mišića od 9. svibnja 1941.", u: Kršćanska obitelj, 5-6/1941., str. 165-166. Nije ustao odmah protiv progona i ubijanja pravoslavnih kršćana, svećenika i monaha po Hercegovini, te protiv maltretiranja i progona episkopa zahumskohercegovačkoga, Nikolaja Jokanovića u Mostaru. Usp. Sima Simić, Hercegovački biskupi za vreme okupacije Jugoslavije, Beograd, 1990., str. 5. Poslije je smogao nešto više snage i počeo osuđivati i javljati u Zagreb sve počinjene ratne zločine po Hercegovini. Usp. Tомо Vuкšıć, "Mostarski biskup Alojzije Mišić (1912.-1942.) za vrijeme Drugog svjetskog rata", (II.), u: Crkva u svijetu, 3/2006., str. 326-342. U rujnu 1941., na pritisak Svete Stolice i zapovijed generala Franjevačkoga reda, objavio je poslanicu u kojoj je ustao protiv ratnoga ubijanja i progona pravoslavnih Srba i Židova. Poslanica nije dostupna, jer još nisu vraćene zaplijenjene ratne godine Arhiva Biskupije u Mostaru. O biskupu Mišiću može se naći opširnije u sljedećoj literaturi: "Naš biskup Presv. g. fra Alojzije Mišić", u: Kršćanska obitelj, 8/1912., str. 170-175; BoRIs IlovačA, "Biskup o. fra Alojzije Mišić", u: Franjevački vjesnik, 36/1919., str. 347-354; FrANJo Lipovac, "+ O. fra Alojzije Mišić, biskup mostarski", u: Glasnik sv. Ante, 37/1942., str. 151-154; Ivo BAGARIĆ, "Pastoralne poslanice biskupa fra Alojzija Mišića", u: MARKo Oršolić (prir.), Fra Josip Markušić. Zbornik, Zagreb - Sarajevo, 1982., str. 269-295; MARкo Perić, "Život i rad mostarsko-duvanjskih i trebinjsko-mrkanskih biskupa u zadnjih 100 godina", u: P. BAвIĆ - M. Zovкıć (prir.), Katolička crkva u Bosni i Hercegovini u XIX i XX stoljeću, Sarajevo, 1986., str. 281-285; Anto Slavko Kovačić, Bibliografija franjevaca Bosne Srebrene, Sarajevo, 1991., str. 259-263; Juro ŠAlić, "Biskup fra Alojzije Mišić", u: Bosna franciscana, 7, Sarajevo, 1997., str. 199-210; Isti, Franjevci sjeverozapadne Bosne, Bihać, 2002., str. 142-148; Ignacije Gavran, "Fra Alojzije Mišić, biskup", u: Vrata u život, Sarajevo, 2000., str. 71-73; Toмo Vuкšıć, "Mostarski biskup Alojzije Mišić (1912.-1942.) za vrijeme Drugog svjetskog rata. Prilog proučavanju međucrkvenih i međunacionalnih odnosa", (I.), u: Crkva u svijetu, 2/2006., str. 215-234.

22 Dopis pročelnika Treščeca Zemaljskom poglavaru generalu Varešaninu 19. veljače 1910. ABH Sarajevo, GFM Präs. BH, 95/1910. Usp. P. VRankić, Religion und Politik, str. 514. 
bosanskih franjevaca prikladnih, po njegovu mišljenju, za pomoćnoga biskupa u Mostaru. ${ }^{23}$ Mišić je obavio ovu povjerljivu misiju u rekordnom vremenu, premda je još uvijek vladala duboka zima u Sa-

23 Mišić u svome Curriculum vitae stavlja odlazak u Mostar poslije smrti biskupa Buconjića, u vrijeme "vakancije biskupije" i izigrava skromnoga, nezainteresiranoga i gotovo neupućena redovnika, koji ne poznaje hercegovačke franjevce. Provincijal Mišić bio je zamoljen početkom veljače 1910. da ode u Mostar. On je to obavio vrlo brzo jer pročelnik Treščec izvještava već 19. veljače o dobro obavljenu poslu provincijala Mišića u Mostaru. Zašto se Mišić tako vlada i piše? Iz demencije, jer je Životopis napisan tek 1941./1942. godine? Iz želje da prikrije svoju ulogu u Vladinim namjerama da se zaobiđu Stadlerovi kandidati i kandidati hercegovačkih franjevaca te da se njega pošalje u Mostar? Uvjerenja smo da ćemo na kraju ovoga prikaza mnogo više saznati. Provincijal Mišić prikazuje svoju hercegovačku subraću, i to ne kao svoje mišljenje, nego kao mišljenje staroga i veoma zaslužnoga hercegovačkog franjevca i sedamdesetogodišnjaka, fra Nikole Šimovića, i piše: "Godine 1910. 8. XII. umro je u Mostaru preuzvišeni g. o. Paškal Buconjić. Mostarska biskupija ostala nepopunjena duže vremena. Tražilo se da se popuni. Za živa Biskupa Buconjića išlo je lako da se popuni in forma cum iure successionis. Buconjić nije to našo za shodno. Zašto? neću da ulazim. Ponavljam, vakancija otegla se po smrti duže nego treba. Vlada je htjela i išla na to. Trebalo sgodna kandidata. Jednom sgodom dojde meni kao Provincijalu Vladin dvorski savjetnik šef kultus odsjeka ko izaslanik Vlade pa me zamoli: Oče Alojzije, otidji u Mostar, razgovori se sa poznatim Vam uglednijim franjevcima izvadi (sic!) njihovo mišljenje, koga oni misle da bi izmedju njih jedan mogo postati Biskup. Molbu i preporuku primio sam; obećao da ću otići u Mostar i otišao. Ja nijesam uopće poznavo nikoga herceg. franjevaca, stoga jer ih osobno nijesam dobro poznavo, nijesam ni mogao reći od sebe ovoga ili onoga. Otišo sam u Mostar, kako mi je rečeno. Došao u Mostar. U Mostaru poznavao sam dobro o. Nikolu Šimovića. O. Nikola bio je dobar redovnik, consultor Biskupu. Iza smrti Biskupa Buconjića Nadbiskup Stadler ko Metropolita za upravitelja Biskupije in spiritualibus naimenovao je Ill[ustrissi]mum don Lazar Lazarević, a za ekonoma dobara Biskupije o. Glavaš Radoslava. Don Lazar bio je dobar upravitelj in spiritualibus." Arhiv Biskupskoga ordinarijata Mostar (dalje: ABO Mostar), Curriculum vitae P. Aloysii Mišić, O.M., str. 19. Curriculum vitae (Životopis) nije paginiran u pravom smislu riječi. Citirana stranica 19 je 19. arak papira i sadržava praktično četiri stranice, kao uostalom i svi drugi arci u ovom $\check{Z} i$ votopisu. Prigodom stogodišnjice imenovanja biskupa Mišića (1912. - 2012.) objavio je mostarsko-duvanjski biskup dr. Ratko Perić one stranice Životopisa, koje se odnose na ovo imenovanje. Usp. Službeni vjesnik biskupijâ Mostarsko-duvanjske i Trebinjsko-mrkanske, 3/2012., str. 296-300. Budući da je Mišićev Životopis u Perićevu izdanju jezično i ortografski prilagođen modernom hrvatskom jeziku, ovdje se služimo originalom i prema njemu citiramo. U Chronici biskupije, međutim, opisuje opširnije krug konzultiranih franjevaca te nadodaje: "Excel. kako znate, po naputku Vlade ja sam 1910. išao u Mostar i propitkivo se med franjevcima, koji bi med njima najprikladniji bio za bisku- 
rajevu. Odlazak u Hercegovinu i traženje kandidata u njegovu Životopisu protuslovan je i nije u skladu sa sličnim opisom koji je ostavio $\mathrm{u}$ Chronici biskupije. ${ }^{24}$ Opis hercegovačkih franjevaca u njegovu je Životopisu, bez sumnje, naivan, pomalo podrugljiv i ne posve iskren, kao da hercegovački franjevci nisu bili članovi iste franjevačke obitelji. U Chronici biskupije, koju je počeo pisati odmah po preuzimanju biskupske službe, piše razboritije i uravnoteženije. ${ }^{25}$

Od hercegovačkih franjevca, premda to ne spominje u Chronici biskupije i u Životopisu, Mišić je predložio četvoricu, bez sumnje, uglednijih, učenih i većinom mlađih svećenika. Tu je prije svega vrlo zaslužan ali prestar i zdravstveno oslabljen eksprovincijal fra Nikola Šimović, ${ }^{26}$ talijanski student sa 71 godinom života, samo pet godina mlađi od biskupa Buconjića i dvadeset godina stariji od Mišića. Zbog svoje poodmakle dobi i nagrižena zdravlja bio je prilično neprikladan. Slijedio je dvadeset i četiri godine mlađi i učeni fra Dujo Ostojić, ${ }^{27}$ koji je kao student pohađao franjevačko učilište u Bolzanu

pa u Hercegovini. Pitao sam za mnenje najuvaženije franjevce. Navodim O. Ambru Miletića Provincijala, O. Nikolu Šimovića, O. Luku Begića. O. Miletić reko mi je, neznam koga bi preporučio. Među nama sada nejma ga. O. Nikola Šimović reče, ako baš treba da bude Hercegovac, preporučio bih O. Dujma Ostojić, ali očekujemo Vas, upre prstom meni. Vas ili nikoga. Pitam dalje, prečasni Vi ste Konsistorialac, Ex Prov. franj; osim O. Dujma Ostojić, imate još koga drugog kandidata? Neodgovori. Šutio. O. Begić Ex Prov. Na pitanje, šta misli, ko bi mogo biti kandidat za biskupa?, šta misli i koga predlaže? Tamo amo ništa izvjesno neodgovori mi." ABO Mostar, Chronika biskupije, str. 1.

24 ABO Mostar, Chronika biskupije, str. 2.

25 "Kad sam došao u Mostar, otišao sam Šimoviću Nikoli i pitao ga što on misli, tko bi mogao između hercegovačkih franjevaca kao zgodan kandidat za Mostar[sku] Biskupiju da postane Biskup u kombinaciju da dojde. Izmedju mene kao provincijala Bosne i o. Šimovića vodio se je pouzdani razgovor o mogućem kandidatu za Biskupa u Mostar. O. Šimović mislio se tamo amo, napokon izjavi: oče Provincijale, naša hercegovačka Provincija za nepriliku kad već moram kazati, nejma zgodne osobe za Biskupa. Sve prevagni, obazri se na ovoga ili onoga - nejma. Jedini koga bih ja mogao imati, jest fra Dujo Ostojić ali ne bih se podpuno založio ni za njega. Nejmamo sgodna. Šta ću? Ostao sam u Mostaru dan dva, vratio se: kazao što sam čuo. Vlada dvorska svakako je htjela u Mostaru da ima franjevca za Biskupa." ABO Mostar, Curriculum vitae, str. 19.

26 Fra Nikola Šimović (Zvirovići, 1839. - Mostar, 1912.), R. Jolić, Leksikon hercegovačkih franjevaca, str. 383-386.

27 Fra Dujo Ostojić (Bijakovići, 1863. - Humac, 1938.), R. Jolić, Leksikon hercegovačkih franjevaca, str. 297-298. 
i Sveučilište u Grazu, a trenutačno bio gvardijan i župnik na Humcu i imao 47 godina. Fra Dujo, premda je bio vrlo učen, nadaren i imao dovoljno životnoga iskustva, posjedovao je u svome karakteru nešto neugodno, što ga je činilo djelomično neprihvatljivim kako kod biskupa Buconjića, tako i kod starije subraće. Tu su bila i dvojica mlađih franjevaca koji sigurno nisu ulazili u uži izbor u tadašnjoj konstelaciji zbog nedostatka životnoga iskustva: fra Špiro Šimić, ${ }^{28}$ vjeroučitelj u gimnaziji u Mostaru, s nepune 42 godine, i fra Pacifik (Mirko) Matijević, ravnatelj Franjevačke gimnazije na Širokom Brijegu, s 38 godina. ${ }^{29}$ Popis prikladnih franjevaca iz Bosne Srebrene za koadjutora u Mostaru sadržavao je imena pet uglednih franjevaca: 1. fra Anđeo Franjo Franjić, ${ }^{30}$ bečki student prirodnih znanosti, nadareni odgojitelj i gvardijan u Fojnici, s 54 godine; 2. učeni i agilni eksprovincijal fra Daniel Ban, ${ }^{31}$ ostrogonski student, trenutačno župnik u Podhumu, općina Konjic, s 53 godine; 3. fra Anđeo Nikola Curić, ${ }^{32}$ student u Đakovu i na franjevačkom učilištu u Gorici (Gorizia), zaslužni eksprovincijal, gvardijan u Gorici kod Livna, sa 71 godinom; 4. fra Grgo Došen, ${ }^{33}$ student franjevačkih učilišta u Firenci i Dubrovniku, župnik na više župa u Posavini, voditelj Rezidencije sv. Jurja u Carigradu, gvardijan u Tolisi, sa 64 godine starosti; 5. na kraju, ugledni povjesničar fra Mijo Vjenceslav Batinić, ${ }^{34}$ student franjevačkoga učilišta u Reggio Emilia u Italiji i biskupskoga učilišta u Đakovu, isto tako sa 64 godine života. Provincijal Mišić potrudio se odmah i osobno uručiti liste predloženih kandidata i pritom se upustio u širi informativni razgovor s pročelnikom Treščecom. U

28 Fra Špiro Šimić (Dragićina kod Gruda, 1868. - Mostar, 1916.), R. Jolić, Leksikon hercegovačkih franjevaca, str. 381-382.

29 Fra Pacifik (Mirko) Matijević (Mokro kod Širokoga Brijega, 1872. - Mostar, 1920.), R. Jolić, Leksikon hercegovačkih franjevaca, str. 350.

30 Fra Anđeo Franjo Franjić (Svinjarevo kraj Kiseljaka, 1856. - Bugojno, 1919.). Usp. Ignacije Gavran, Hrvatski franjevački biografski leksikon, (dalje: HFBL), Zagreb, 2010., str. 177.

31 Fra Daniel Ban (Kreševo, 1857. - Kreševo, 1939.). Usp. Anto Slavko Kovačić, $H F B L$, str. 36.

32 Fra Anđeo Nikola Ćurić (Korin kraj Livna, 1839. - Gorica kraj Livna, 1917.). Usp. A. S. Kovačić, HFBL, str. 127-128.

33 Fra Grgo Došen (Ugljara pokraj Tolise, 1846. - Tolisa, 1919.). Usp. Župnici župe Garevo (1839. - 1889.). www.garevac.net/tekst/539 (11. 6. 2018.).

34 Fra Mijo Vjenceslav Batinić (Fojnica, 1846. - Fojnica, 1921.). Usp. A. S. KovAČIć, HFBL, str. 46-47. 
razgovoru je mogao dodati osobne vijesti za svakoga od predloženih kandidata. Lista kandidata hercegovačkih franjevaca bila je tako vrlo vješto složena da nijedan od četvorice predloženih nije mogao doći u uži izbor kod Vlade: Šimović prestar i bolestan, Ostojić sposoban ali od braće neprihvaćen, dvojica preostalih kandidata premladi i neiskusni. Time je već bila pala odluka da prikladna kandidata treba tražiti samo među bosanskim franjevcima. No, i lista bosanskih kandidata, za manje upućene, bila je još spretnije sastavljena od one hercegovačke. Mišić je znao dobro što čini. Njegova je lista ciljala manje na sposobnost i prikladnost predloženih franjevaca, više na samostansku zastupljenost, ravnotežu i mir u provinciji Bosne Srebrene. Vrlo utjecajan samostan Fojnica bio je zastupljen s dva kandidata, jedan već prestar za službu koadjutora (povjesničar Batinić), dok je drugi, Franjić, bio preslaba zdravlja za takvu službu. Kandidat iz samostana Tolisa, Došen, bio je isto tako prestar i iscrpljen sa svoje 64 godine, ali još uvijek ne tako kao kandidat iz samostana Gorica, Ćurić, koji je imao 71 godinu. Ostao je jedino kandidat kreševskoga samostana, fra Danijel Ban, s 53 godine, ostrogonski student, doktor Sveučilišta u Beču, eksprovincijal, redovnik koji je bio poznat po svojoj intelektualnoj visini, crkvenoj, školskoj i prosvjetiteljskoj revnosti. Provincijal Mišić, ukoliko se nadao biskupskoj stolici u Baru, koju mu je obećao fra Dionizije Schuler, general Reda, ${ }^{35}$ ili u Banjoj Luci, gdje ga je želio imati biskup Marković, ${ }^{36}$ ciljao je najvjerojatnije na fra Danijela Bana kao koadjutora i poslije kao ordinarija u Mostaru. Time je istovremeno umješno pripremao teren za sebe kao nasljednika fra Marijana Markovića, biskupa i upravitelja Banjolučke biskupije. No, u cijeloj ovoj pripravi oko koadjutora u Mostaru promaknulo je Mišiću nešto što on nije znao ili je znao, ali je radije htio prešutjeti pred Vladinim predstavnikom i prijateljem: Skrivene, vrlo teške i nedostojne optužbe fra Danijela Bana i sabornika Sunarića protiv nadbiskupa Stadlera. Ako su Mišiću optužbe subrata fra Danijela protiv nadbiskupa Stadlera bile promakle ili ih je on prešutio, one su svakako bile već poznate Vladi u Sarajevu i ona je, usprkos svakodnevnim političkim napetostima s vrhbosanskim nadbiskupom, dobro poznavala Stadlerov moralni integritet, i nije mogla dopustiti da takvo nešto bude prošireno među pukom, političkim istomišlje-

35 ABO Mostar, Curriculum vitae, str. 19. Usp. dolje bilj. 84 i pripadajući tekst. 36 ABO Mostar, Curriculum vitae, str. 19. 
nicima, protivnicima i inovjercima, od jednoga budućeg biskupa. ${ }^{37}$ Stoga ni fra Danijel Ban nije mogao doći u obzir za koadjutorsko mjesto u Mostaru. Razgovor s pročelnikom Treščecom imao je za Mišića neočekivano pozitivan ishod. Nakon razgovora dolazi Treščec, kako će on kasnije javiti u Zemaljsku vladu, do zaključka da je Mišić, koji je uostalom bio njegov kućni prijatelj, bio bolji kandidat od svih drugih koji su bili nabrojeni u Hercegovini i u Bosni. Stoga on predloži 19. veljače 1910. provincijala Mišića za biskupa koadjutora u Mostaru. ${ }^{38}$ Ovom prijedlogu pridružio se i Karl Pittner, prijašnji okružni predstojnik u Mostaru, uvijek odbojno raspoložen prema hercegovačkim franjevcima i hrvatski orijentiranoj eliti u Mostaru. ${ }^{39}$ U svom dopisu od 22. veljače zemaljskom poglavaru, generalu Marijanu Varešaninu, ${ }^{40}$ preporučuje provincijala Mišića kao jedinoga pravoga kandidata za Mostar. ${ }^{41}$ Zemaljski doglavnik Benko sažima sve ove prikupljene vijesti i mišljenja te ih upućuje 27. ožujka 1910. ministru Buriánu u Beč i preporučuje provincijala Mišića kao jedinoga prikladnoga kandidata za pomoćnoga biskupa u Mostaru. ${ }^{42} \mathrm{U}$ Beču i u Sarajevu morala je stvar mirovati nekoliko mjeseci jer su nastupile velike pripreme za posjet cara Franje Josipa Bosni i Hercegovini. Tijekom carskoga posjeta Bosni i Hercegovini i nakon toga pojavljuju se dodatni akteri i kandidati. Istovremeno se rasplamsao oštar sukob između nadbiskupa Stadlera i bosansko-hercegovačkih franjevaca te između dvije hrvatske stranke: od franjevaca dominirane Hrvatske narodne zajednice i od Stadlera osnovane i podupirane

37 Optužbe sabornika Sunarića i eksprovincijala Bana mogle su se naći 1988. godine u Arhivu BiH te u ostavštini apostolskoga delegata Bastiena.

38 Dopis pročelnika Treščeca Zemaljskom poglavaru generalu Varešaninu 19. veljače 1910. ABH Sarajevo, GFM Präs. BH, 95/1910. Usp. P. VRankić, Religion und Politik, str. 514.

39 P. VRankić, Religion und Politik, str. 576.

40 Barun Marijan Varešanin od Vareša (Gunja, Hrvatska, 1847. - Beč, 1917.), od 1905. austro-ugarski general topništva, zemaljski poglavar BiH (1909. - 1911.). Primio je 1910. cara Franju Josipa u Sarajevu prigodom njegova pohoda BiH. Tjedan dana kasnije, član srpske "Crne ruke", Bogdan Žerajić, izvršio je na njega neuspjeli atentat, ranivši ga teško. Barun Varešanin je osobno 1912. prenio kosti svoje pokojne majke iz Beča u selo Oćevije kod Vareša, odakle je bila rodom. Usp. Hrvatska enciklopedija, (dalje: HE), 11, Zagreb, 2009., str. 285.

41 Dopis baruna Pittnera generalu Varešaninu 22. veljače 1910. ABH Sarajevo, GFM Präs. BH, 95/1910; P. VRANKIĆ, Religion und Politik, str. 514.

42 Dopis baruna Benka ministru Buriánu 22. ožujka 1910. ABH Sarajevo, LR Präs., 1347/1910; P. VRANKIĆ, Religion und Politik, str. 514. 
Hrvatske katoličke udruge, što je dovelo do velike političke i crkvene podjele među bosansko-hercegovačkim katolicima Hrvatima. ${ }^{43}$

\subsection{Kandidati biskupa Buconjića}

Nakon dugih i napornih pregovora, usuglašavanja te ustavne ankete, donio je car Franjo Josip 17. veljače 1910. ustavnu uredbu kojom je Bosna i Hercegovina dobila svoj prvi Zemaljski ustav. Neposredno nakon toga, 20. veljače 1910., Zemaljski ustav bio je svečano proglašen u dvorani Zemaljske vlade u Sarajevu. Od toga trenutka počele su se širiti glasine o skorom dolasku cara Franje Josipa u BiH. Istovremeno, u proljeće 1910., po Hercegovini se počeo širiti glas o namjeri Vlade u Sarajevu i u Beču da nametne čovjeka od svoga povjerenja, provincijala Mišića, za biskupa koadjutora u Mostaru. Najvjerojatnije je i biskup Buconjić doznao od hercegovačkih franjevaca ili od Stadlerova kruga ime kandidata Vlade za koadjutorsko mjesto u Mostaru. U svojoj zatvorenosti i nepovjerenju, koje ga je pratilo posljednjih godina, biskup Buconjić nije više znao ili mogao pokloniti dužnu pažnju savjetima i željama svojih nekada bližih suradnika o potrebi imenovanja koadjutora s pravom nasljedstva. Dok su pojedini iskusni hercegovački franjevci poput Šimovića, Begića, Miletića, Ostojića i Glavaša, kao i neki drugi, vidjeli imenovanje koadjutora ne samo kao veliku priliku za svoje vlastito promaknuće, nego i kao šansu za rast i promaknuće Crkve u Hercegovini, Buconjić je doživljavao imenovanje koadjutora kao osobno razvlaštenje te se grčevito borio protiv njega. No, ova Buconjićeva politička i crkvena neagilnost i osobna nesklonost prema starijim hercegovačkim franjevcima iritirala je stariju subraću, posebno tadašnjega uglednog franjevca i provincijala fra Luku Begića. Stoga se on 3. lipnja 1910. u svojoj redovničkoj samouvjerenosti i u nepunoj šezdesetdevetoj godini života, sam preporučuje za biskupa koadjutora u Mostaru otvorenom predstavkom caru Franji Josipu za vrijeme njegova posjeta Mostaru. Posebno patetične ali i vrlo hrabro zvuče njegove riječi: "Na ovoj krajnjoj točci Tvoga velikog Carstva i na najjužnijoj točci Hrvatskog kraljevstva držat će stražu stalno uz vojnika redovnik, uz carskog ratnika stajat će fra-

43 Usp. Luka ĐAкović, Političke organizacije bosanskohercegovačkih katolika Hrvata, Zagreb, 1985., str. 325-353; Zoran GriJak, Politička djelatnost vrhbosanskog nadbiskupa Josipa Stadlera, Zagreb, 2001., str. 454-526. 
njevac. Vojnik će Ti čuvati granicu, redovnik unutrašnjost." ${ }^{14}$ Begićev potez iz 1910. podsjeća, bez sumnje, na onaj hrabri potez provincijala Buconjića iz daleke 1875. godine. Tada je car Franjo Josip I. posjećivao Dalmaciju i ususret su mu pohrlili na granična mjesta politički svjesniji ujaci iz Hercegovine i iz Livanjskoga kraja. Dok je fra Lovro Karaula osvetom dobrih susjeda, livanjskih muslimana, platio glavom, među ostalim i svoj posjet Caru, Buconjić se brzo sklonio u Dalmaciju, preživio i pet godina kasnije postao biskup u Hercegovini po milosti istoga cara Franje Josipa. Sada, isto tako, provincijal Begić iskorištava svoju priliku prigodom Careva obilaska Bosne i Hercegovine, posebno prigodom njegova posjeta Mostaru 3. lipnja 1910.

U međuvremenu, netko iz kruga povjerljivih osoba, uspio je upozoriti Buconjića na već konkretne namjere Sarajeva, Beča, Rima, ali i na planove provincijala Begića o imenovanju koadjutora. Buconjić, u posljednji čas, da bi pretekao planove Vlade te isposlovao izbor i imenovanje koadjutora po svojoj želji, obraća se u lipnju 1910. papi Piju X. i šalje mu imena trojice, prema njegovu mišljenju, prikladnih i njemu odanih kandidata. ${ }^{45}$ To su bili: 1 . fra Frano Lulić, ${ }^{46}$ dalmatinski franjevac i generalni definitor Reda u Rimu u to doba; 2. hercegovački franjevac, fra Špiro Šimić, ${ }^{47}$ gimnazijski vjeroučitelj u Mostaru i 3. fra David Nevistić, ${ }^{48}$ isto tako hercegovački franjevac, tadašnji župnik u Mostaru. Nedugo poslije toga, 27. lipnja 1910., najvjerojatnije upozoren da samo Car ima pravo imenovanja biskupa u BiH, a Papa pravo potvrđivanja, Buconjić se obraća konačno caru Franji Josipu, šaljući mu preko Vlade u Sarajevu imena trojice spo-

44 Citirano prema njemačkom prijevodu, koji posjedujemo. Hrvatski original nismo našli: "An diesem äußersten Punkte Deines großen Kaiserreiches und dem südlichsten des kroatischen Königreiches wird neben den Soldaten der Ordensbruder unentwegt Wache stehen, neben dem kaiserlichen Krieger der Franziskaner; der Soldat wird Dir die Grenze schützen, der Ordensbruder auch das Innere." Usp. predstavku fra Luke Begića caru Franji Josipu, 3. lipnja 1910. ABH Sarajevo, GFM Präs. BH, 1052/1910; P. VRankić, Religion und Politik, str. 514, 576.

45 Zamolba biskupa Buconjića caru Franji Josipu, 27. lipnja 1910. ABH Sarajevo, GFM Präs. BH, 1001/1910; P. VRANkić, Religion und Politik, str. 514.

46 Fra Frano Lulić (Igrane-Makarska, 1864. - Zagreb, 1929.). Usp. Josip AnTE Soldo, HFBL, str. 346.

47 Vidi gore bilješku br. 28.

48 Fra David Nevistić (Tomislavgrad, 1870. - Sarajevo, 1922.), R. Jolić, Leksikon hercegovačkih franjevaca, str. 285-286. 
menutih kandidata i moli ga za imenovanje koadjutora. ${ }^{49}$ Predloženi Buconjićevi kandidati vrijedni su kratka komentara. Prvi među njima, fra Frano Lulić iz Igrana kod Makarske, nalazio se tada u Rimu kao generalni definitor. Prije toga bio je župnik, ravnatelj gimnazije u Sinju, član uprave i provincijal Provincije Presvetoga Otkupitelja i slovio je kao dobar pedagog i uvažen gimnazijski učitelj. Budući da je u Rimu doktorirao kanonsko pravo, bio je ipso facto vrlo prikladan za biskupsku službu. Istovremeno, kao nekadašnji dalmatinski provincijal i hercegovački susjed, poznavao je dobro i župsku i franjevačku praksu kako u Dalmaciji, tako i u Hercegovini. Sa svojih 46 godina bio je u idealnim godinama za biskupsku službu. Zašto je on za biskupa Buconjića bio prvi i glavni kandidat? Posljednjih godina svoga života biskup Buconjić bio je razočaran držanjem pojedine subraće iz bližega kruga savjetnika i suradnika kao i iz redova uprave Provincije, što nije predmet ovoga istraživanja. Stavljanjem Lulića na prvo mjesto Buconjić je, bez sumnje, povrijedio ponos uglednijih hercegovačkih franjevaca kao što su bili Šimović, Begić, Miletić i Ostojić. No, i osim toga, ako se apstrahira od povrijeđena ponosa i dalmatinsko-hercegovačkoga lokalpatriotizma, Lulić je mogao biti idealno rješenje za Hercegovinu. Dvojica drugih kandidata, Šimić i Nevistić, premda su bili vrijedni i zapaženi redovnici u svojoj sredini, bili su u njegovim očima još premladi i samo figure, koje su popunjale predloženu ternu/trojku. Ovdje treba posebno istaknuti mladoga i sposobnoga insbruškog studenta fra Davida Nevistića, jednoga od najagilnijih hercegovačkih franjevaca na početku 20. stoljeća te člana uprave Provincije (1910. - 1913.) i provincijala (1916. - 1919.). Zanimljivo je da se među Buconjićevim kandidatima ne nalaze dvojica vrlo nadarenih i sposobnih franjevaca, posljednjih Buconjićevih tajnika: fra Dujo Ostojić i fra Radoslav Glavaš. Zemaljska vlada, pročitavši molbenicu biskupa Buconjića i njegovu listu, komentirala je na svoj način predložene kandidate. Ona je smatrala Franu Lulića neprikladnim kandidatom, jer je živio u Rimu i da ga nitko nije poznavao. Kao rođeni Dalmatinac, Lulić ne bi naišao na dobrohotno prihvaćanje kod redovničkoga svećenstva i kod puka u Hercegovini, komentirala je dalje Vlada. Pravi razlog njegove neprikladnosti treba tražiti u odbojnosti Beča, a još više Pešte prema svemu što je dolazilo iz Rima i što nije bilo zadahnuto takozvanim neojozefinističkim, liberalnim duhom Monarhije. Dalje, po mišljenju Vlade, od dvojice

49 Zamolba biskupa Buconjića caru Franji Josipu, 27. lipnja 1910. ABH Sarajevo, GFM Präs. BH, 1001/1910; P. VRankić, Religion und Politik, str. 514. 
kandidata između hercegovačkih franjevaca, fra David Nevistić zaslužuje svakako prednost pred fra Špirom Šimićem. No, nijedan od njih dvojice ne može se mjeriti po svome ugledu, svojim karakteristikama i prikladnosti s provincijalom Mišićem. Stoga se Zemaljska vlada još jedanput najodlučnije založila za svoga kandidata Mišića. ${ }^{50}$

Zajedničko ministarstvo financija, nakon što je proučilo cijeli predmet, upućuje svoju molbu i namjeru Zajedničkome ministru vanjskih poslova, grofu Aehrenthalu ${ }^{51}$ i moli za uredovanje u Rimu kod Svete Stolice. ${ }^{52}$ Aehrenthal zadužuje 27. lipnja 1910. veleposlanika Dvojne Monarhije pri Svetoj Stolici, grofa Szécsena, ${ }^{53}$ da izvijesti Državno tajništvo o namjeri Cara i njegove Vlade s obzirom na imenovanje koadjutora u Mostaru. ${ }^{54}$ Grof Szécsen, veleposlanik jedine katoličke velesile onoga vremena, stupio je vrlo brzo u kontakt s Državnim tajnikom, kardinalom Rafaelom Merry del Valom, ${ }^{55}$ radi imenovanja koadjutora u Mostaru. U audijenciji, kada je predložio Mišića, kandidata Vlade, grof Szécsen doznao je da je Državno tajništvo u posjedu liste kandidata biskupa Buconjića, na kojoj nije stajao kandidat Monarhije. U daljnjem razgovoru Merry del Val naveo je da je Mišić

50 Dopis zemaljskoga poglavara generala Varešanina od 6. srpnja 1910. ministru Buriánu. ABH Sarajevo, ZV 3842/1910; P. VRankić, Religion und Politik, str. 515.

51 Alois Graf Lexa von Aehrenthal (Dvorac Hrubá Skála, Češka, 1854. - Beč, 1912.), austro-ugarski diplomat, veleposlanik u Rusiji (1899. - 1906.), ministar vanjskih poslova (1906. - 1912.). U doba njegova službovanja na Ballhausplatzu bila je 1908. anektirana Bosna i Hercegovina, što će biti jedan od uzroka Prvoga svjetskog rata. Usp. F. Roy BRIDGE, The Habsburg Monarchy: Among the Great Powers, 1815-1918, New York, 1990., str. 288-344.

52 Vidi se iz prijepisa dopisa grofa Szécsena grofu Aehrenthalu, 5. srpnja 1910., ABH Sarajevo, GFM Präs. BH, 1095/1910.

53 Nikola Szécsen Graf von Temerin (Temerin, 1857. - Gyöngyösszentkereszt, 1926.), bio je pročelnik u Ministarstvu vanjskih poslova, veleposlanik pri Svetoj Stolici (1901. - 1911.) i u Parizu (1911. - 1914.). Usp. Alois Hudal, Die österreichische Vatikanbotschaft 1806-1918, München, 1952., str. 255-273; FrIEDRICH ENGEL-JANOssi, Österreich und der Vatikan 1846-1918, I., Graz - Wien - Köln, 1958., str. 299, 306; P. VRANKIĆ, Religion und Politik, str. 514.

54 Prijepis dopisa grofa Szécsena grofu Aerenthalu, od 5. srpnja 1910. ABH Sarajevo, GFM Präs. BH, 1095/1910; usp. P. VRANkić, Religion und Politik, str. 513-514.

55 Rafael Merry del Val (London, 1865. - Vatikan, 1930.), španjolski markiz, papinski diplomat, antimodernist, kardinal državni tajnik (1903. - 1914.) pape Pija X., stajao je pod jakim utjecajem austro-ugarske diplomacije. MARTIN BRÄUER, Handbuch der Kardinäle. 1846-2012., Berlin - Boston, 2014., str. 200-201. 
vrijedan svećenik (ein braver Priester), inače nesposoban i premalo nadaren. Iznenađen ovom izjavom, grof Szécsen, u svojoj jednostranosti, odmah je vidio u nadbiskupu Stadleru izvor jedne ovako nepovoljne vijesti za Mišića, i ustvrdio da je to nadbiskup Stadler napisao kako bi mogao promovirati jednoga drugoga kandidata. Kardinal Merry del Val odbio je ovo difamiranje Stadlera od grofa Szécsena, ali mu nije otkrio izvor nepovoljnih vijesti o provincijalu Mišiću. $\mathrm{Na}$ kraju, grof Szécsen zamolio je kardinala Merry del Vala da se i drugdje raspita o Vladinu kandidatu Mišiću, što mu je kardinal dobrohotno obećao. ${ }^{56}$

Želje i prijedlozi biskupa Buconjića, te želje i planovi Vlade u Sarajevu i u Beču za imenovanje biskupa koadjutora u Mostaru, nisu se dale tako brzo usuglasiti sa željama i predodžbama Rima. Stoga Sveta Stolica nije žurila izjasniti se za jednoga ili drugoga od predloženih kandidata. Obje su strane shvatile da treba čekati na skoro naravno rješenje, koje je uslijedilo 8. prosinca 1910. Naime, toga je dana umro biskup Buconjić u 77. godini života i nakon tridesetogodišnjega plodnog biskupskog djelovanja u Hercegovini. Pokopan je u nekadašnjoj katedrali, tada već franjevačkoj župnoj crkvi u Mostaru. Za vrijeme svoga biskupovanja trudio se materijalno osigurati prvenstveno franjevačku provinciju, iz koje je potekao. Zalagao se djelomice i za svoju biskupiju, no nije pretjerao. U posljednjim godinama i danima njegova života, što se tiče biskupije, bilo je mnogo toga opet izgubljeno. ${ }^{57}$ Kako? O tome daju nešto naslutiti njegovi nasljednici. ${ }^{58}$

56 Dopis grofa Szécsena grofu Aerenthalu, od 5. srpnja 1910. ABH Sarajevo, GFM Präs. BH, 1095/1910; P. VRAnkić, Religion und Politik, str. 513-514. Svakako još pogledati: Dopis grofa Szécsena grofu Aerenthalu, od 24. svibnja 1910. HHStA Wien, 34705-6/1910. Usp. k tomu: Z. GriJa K, Politička djelatnost vrhbosanskog nadbiskupa Josipa Stadlera, str. 464-645.

57 ABO Mostar, Chronika biskupije, str. 7.

58 O propasti ili nestanku prikupljenih financijskih sredstava biskupije Mostar razgovarao sam naširoko u srpnju 1982. godine s tada umirovljenim mostarskim nadbiskupom dr. Petrom Čulom. Kao višegodišnji konzultor biskupa Mišića čuo je od njega ovo objašnjenje: Posljednjih godina svoga života biskup Buconjić bio je vrlo onemoćao, kako tjelesno tako i duševno. Uprava Biskupije, kako duhovna tako i materijalna, nalazila se u rukama njegova tajnika i de facto generalnoga vikara fra Radoslava Glavaša, koji je financijska sredstva Biskupije usmjeravao u Franjevačku provinciju. 


\section{Traženje nasljednika biskupu Buconjiću}

\subsection{Stadlerova lista kandidata za mostarskoga biskupa}

Nakon smrti biskupa Buconjića, trebao je, kako propisuje kanonsko pravo, reagirati metropolit i nadbiskup Stadler. On je to učinio 19. prosinca 1910. i imenovao don Lazara Lazarevića, ${ }^{59}$ ugledna svećenika Trebinjsko-mrkanske biskupije i pitomca Urbanova zavoda u Rimu, upraviteljem biskupija Mostar-Duvno i Trebinje-Mrkan in spiritualibus, u duhovnim stvarima. Upravu biskupije in materialibus, u materijalnima dobrima, povjerio je fra Radoslavu Glavašu, tajniku biskupa Buconjića u posljednjih šest godina. Stadlerova imenovanja novih upravitelja pokazat će se samo djelomično uspješna. Dok se uprava u duhovnim stvarima nalazila u dobrim i crkveno-sigurnim rukama, istovremeno, kako se kasnije pokazalo, upravljanje materijalnim dobrima Mostarsko-duvanjske i Trebinjsko-mrkanske biskupije nije bilo uspješno. Fra Radoslav Glavaš nije uspio razlikovati dobra biskupije Mostar-Duvno od dobara Hercegovačke provincije Marijina Uznesenja. Neposredno poslije Buconjićeve smrti, dopisom od 19. prosinca 1910., Stadler je izvijestio Zemaljsku vladu o poduzetim imenovanjima biskupijskih upravitelja u Hercegovini. ${ }^{60}$ Istim dopisom nadbiskup Stadler kandidirao je trojicu vrhbosanskih svećenika za upražnjenu Mostarsko-duvanjsku biskupiju. Svoj korak opravdavao je "žalosnim prilikama", koje su vladale u pogledu dušobrižništva i crkvenoga upravljanja među hercegovačkim katolicima, te je predložio, po svome uvjerenju, trojicu uzornih i sposobnih sveće-

59 Don Lazar Lazarević (Hotanj Hutovski, 1838. - Mostar, 1919.), studirao je teologiju na Urbanovu zavodu Svetoga Zbora za širenje vjere na Španjolskom trgu u Rimu. U istom zavodu bio je ređen za svećenika 1865. godine. Vrativši se u domovinu bio je imenovan župnikom u Stocu i od 1867. provikarom Trebinjsko-mrkanske biskupije. Nakon što je 1890. godine biskup Buconjić preuzeo upravljanje Trebinjsko-mrkanskom biskupijom, Lazarević se preselio u Mostar i bio imenovan biskupovim savjetnikom za tek preuzetu biskupiju. Uvijek se snažno zalagao za samostalnost Trebinjsko-mrkanske biskupije i za njezina vlastita biskupa. Od prosinca 1910. do srpnja 1912. bio je upravitelj in spiritualibus Mostarsko-duvanjske i Trebinjsko-mrkanske biskupije. Umro je 1919. u Mostaru i pokopan pred župnom crkvom u Gracu. Usp. Ratko Perić, Da im spomen očuvamo, Mostar, 2000., str. 474.

60 Dopis nadbiskupa Stadlera Zemaljskoj vladi, od 19. prosinca 1910. AVO Sarajevo, 1360/1910; ABH Sarajevo, GFM Präs. BH, 4/1911; P. VRAnkić, Religion und Politik, str. 516. 
nika, za upražnjeno mjesto: 1 . vrhbosanski pomoćni biskup dr. Ivan Evanđelist Šarić, 2. vrhbosanski kanonik Tomo $\operatorname{Igrc}^{61}$ i 3. gimnazijski vjeroučitelj u Sarajevu dr. Ivan Dujmušić. ${ }^{62}$ Zanimljivo je da Stadler izričito navodi da se informirao i o hercegovačkim franjevcima, ali pred svojom savjesti nije mogao preporučiti nijednoga od njih. ${ }^{63}$ Sva trojica njegovih kandidata bili su, bez sumnje, profilirani svećenici Vrhbosanske nadbiskupije. Dok je kanonik Igrc sa svojih punih 49 godina imao prikladnu dob za biskupsku službu, dotle su pomoćni biskup Šarić, koji je tek bio navršio četrdeset godina i vjeroučitelj Dujmušić sa samo 33 godine, bili premladi za ovu odgovornu službu u Mostaru. Prenaglašena mladost i nedostatak svjetovnih svećenika u $\mathrm{BiH}$ postaje razumljiva kada se ima pred očima da je redovita hijerarhija bila uvedena 1881., gimnazija za spremanje svećenika u Travniku bila otvorena 1882. i da je bogoslovno sjemenište za odgoj i izobrazbu dijecezanskoga klera u $\mathrm{BiH}$ proradilo tek 1890. godine. Biskup Šarić bio je već u siječnju 1910. predložen za biskupa koadjutora u Mostaru. ${ }^{64}$ No, Zemaljska vlada u Sarajevu i Ministarstvo u Beču nisu ga uzeli u obzir zbog njegove vjerske, političke i duhovne blizine s nadbiskupom Stadlerom. Osim ovih nedostataka, po mišljenju Vlade, lista nadbiskupa Stadlera, kao i ona provincijala Mišića, patila je od istoga bosanskoga kompleksa superiornosti. Obje su sadržavale imena samo bosanskih svećenika i redovnika što već i u ono doba nije moglo naići na odobravanje, kako među hercegovačkim franjev-

61 Tomo Igrc (Zelina, 1861. - Sarajevo, 1938.), svećenik Zagrebačke nadbiskupije. Na zamolbu nadbiskupa Stadlera prešao je 1894. godine u službu Vrhbosanske nadbiskupije i služio je u Sarajevu kao nadbiskupski tajnik, župnik u katedrali, kanonik Vrhbosanskoga kaptola i apostolski protonotar. Godine 1926. odrekao se kanoničke službe te je i dalje služio kao duhovnik sestara Služavki Maloga Isusa u Dolorozi u Čardaku i u zavodu Egipat. Umro je 20. kolovoza 1938. i pokopan je na groblju sv. Josipa u Sarajevu. Usp. Vrhbosna, 10/1938., str. 230-231.

62 Ivan Dujmušić (Travnik, 1877. - Sarajevo, 1937.), pitomac Nadbiskupske gimnazije u Travniku, insbruški student i doktor teologije istoga sveučilišta. Služio je kao srednjoškolski kateheta u Tuzli i u Sarajevu te ugledan i dugogodišnji urednik Vrhbosne. Objelodanjivao je u hrvatskoj periodici i nastupao vrlo često u duhu svoga vremena snažno prohrvatski i proapologetski. Usp. Vera Humski, "Ivan Dujmušić", u: Hrvatski biografski leksikon, 3, Zagreb, 1993., str. 679.

63 Dopis nadbiskupa Stadlera Zemaljskoj vladi, od 19. prosinca 1910. AVO Sarajevo, 1360/1910; ABH Sarajevo, GFM Präs. BH, 4/1911; P. VRANkić, Religion und Politik, str. 516.

64 Usp. bilješku br. 12 i pripadajući tekst. 
cima, tako ni u kleru Mostarsko-duvanjske i Trebinjsko-mrkanske biskupije. Premda je nadbiskup Stadler već od 1905. godine podupirao želje trebinjsko-mrkanskoga klera za imenovanje vlastita biskupa ${ }^{65}$ ove želje nisu našle mjesta u listi kandidata. Stadlerovu listu s predloženim kandidatima otpisala je vrlo brzo Zemaljska vlada u Sarajevu. General Varešanin već 31. prosinca 1910. upućuje dopis ministru Buriánu i odbacuje Stadlerove prijedloge s obrazloženjem da iz višekratno ponovljenih razloga ne želi udovoljiti njegovu zahtjevu, popunjenja prazne biskupske stolice u Mostaru imenovanjem dijecezanskoga svećenika na mjesto franjevca i tako mijenjati postojeći status, tj. želi da franjevac ostaje i dalje biskup u Mostaru. ${ }^{66}$ Poslije ovoga jasnog stajališta kako Zemaljske vlade, tako sigurno i Zajedničkoga ministarstva, stvar je mirovala, odnosno čekala na konačan dogovor između Svete Stolice i carskoga Beča.

\subsection{Mišićevo proturječno "sjećanje" na izbor biskupa u Mostaru}

Kada se studira Mišićeva Chronika biskupije i Životopis, dolazi se do nekih novih spoznaja koje nisu u skladu s arhivskim svjedočanstvima. Dok su zapisi u Chronici biskupije pisani odmah poslije preuzimanja uprave biskupije (21. srpnja 1912.), dotle su njegova zapamćenja iz Životopisa pisana tek 1941./1942. Često se stječe dojam da se biskup Mišić nije više mogao ili se nije potrudio točno prisjetiti kako je to bilo s biskupskim imenovanjem u Mostaru 1910. - 1912. godine. Mišić, premda je bio kandidat Vlade za biskupa u Mostaru i istodobno njezin savjetnik u traženju drugih prikladnih kandidata, nije imao uvida u sve planove Vlade i Svete Stolice te često miješa razdoblje prije i poslije smrti biskupa Buconjića, ne spominje sve kandidate i pokušava prikriti da teži za episkopatom, "časnom službom" (usp. 1 Tim 3,1) u Mostaru. Ipak, njegova sjećanja iz Chronike biskupije i Životopisa tumače neke događaje, koji se ne mogu naći u drugoj ar-

65 Dopis Zemaljske vlade ministru Buriànu, 6. studenoga 1906.; ABH Sarajevo, LR Res. 2032/1906; P. VRANkić, Religion und Politik, str. 535.

66 Der Tendenz Seiner Exzellenz des Herrn Erzbischof Dr. Stadler, den vakanten Mostarer Bischofsitz für einen Weltgeistlichen zu sichern, vermag die Landesregierung aus den schon wiederholt dargelegten Gründen, welche für die Erhaltung des Status quo beziehungsweise für die Besetzung des in Rede stehenden Bischofsitzes mit einem Franziskaner sprechen, nicht beizupflichten. Dopis generala Varešanina ministru Buriànu, 31. prosinca 1910. ABH Sarajevo, LR Präs. 7772/1910; P. VRAnkić, Religion und Politik, str. 516. 
hivskoj građi, te otkrivaju nove spoznaje i nove aktere. Biskup Mišić, kao kroničar, daje naslutiti višestruku utrku za biskupskom stolicom u Mostaru. S prijedlozima i listama kandidata za biskupa u Mostaru 1910. - 1911. bili su u Hercegovini nezadovoljni biskup Buconjić, dok je još bio živ, zatim franjevci i biskupijski svećenici. Kler Trebinjskomrkanske biskupije tražio je ponovo za sebe vlastita biskupa u Trebinju. Njihovu želju i planove podupirao je prilično mlako nadbiskup Stadler. Želje i planovi trebinjskih svećenika samo su se djelomice poklapali sa Stadlerovim namjerama. Dok će trebinjski kler isticati svoga kandidata za biskupa, najprije u osobi vremešna don Lazara Lazarevića, ${ }^{67}$ kasnije u osobi don Anđelka Glavinića, ${ }^{68}$ župnika u Trebinju, dotle je Stadler imao svoje planove. On je u prvom redu želio da bude imenovan biskupom u Trebinju, zaobilazeći trebinjski kler, njegov generalni vikar Stjepan Hadrović. ${ }^{69}$ Svećenstvo Trebinjsko-mrkanske biskupije, doznavši za prave namjere nadbiskupa Stadlera, osjetilo se izdano i sučelilo se njegovim planovima, isključujući Hadrovića, unatoč njegovu nagovaranju po Hercegovini. ${ }^{70} \mathrm{~S}$ obzirom

67 Mišić piše: "Osim Šarića govorkalo se, to mi je Dr. Shek, šef pravosudja, saopćio, iznosi se da za kandidata na stolicu Biskupa Mostar - upravitelj biskupije Mostar Don Lazar Lazarević." ABO Mostar, Curriculum vitae, str. 19.

68 Don Anđelko Glavinić (Stolac, 1856. - Trebinje, 1918.), pitomac Urbanova zavoda u Rimu (1874. - 1883.), bio je zaređen za svećenika 1883. godine. Po povratku u domovinu službovao je kao kapelan na Lastovu, župnik u Hrasnu (1885. - 1890.), te kao prvi župnik u Trebinju (1890. - 1918.), sve do svoje prerane smrti. Glavinić je našao u Trebinju već dogotovljenu župnu crkvu/katedralu i u međuvremenu je sagradio novu župnu kuću. Vršio je službu trebinjskoga dekana (1892. - 1918.). Papa Pio X. imenovao ga je komornikom (monsinjorom). Rat ga je omeo u njegovim graditeljskim planovima. Bio je pobožan i radišan svećenik, srednjih intelektualnih sposobnosti, no još uvijek prikladan za vođenje jedne manje biskupije. Usp. R. Perić, Da im spomen očuvamo, str. 197-198.

69 Stjepan Hadrović (Vrbovac kod Ozlja, 1863. - Pale kod Sarajevo, 1934.), glazbeno vrlo nadaren svećenik Zagrebačke nadbiskupije, zaređen 1888., prešao je, po želji nadbiskupa Stadlera, 1891. godine u službu Vrhbosanske nadbiskupije i postao prvi orguljaš i zborovođa u novosagrađenoj katedrali u Sarajevu. Slijedile su službe nadbiskupskoga tajnika (1893.), vrhbosanskoga kanonika (1894.) i generalnoga vikara (1904.). Iz Rima su stigla prelatska i protonotarska imenovanja. Sahranjen je u kapelici na groblju sv. Josipa u Sarajevu. Usp. Marko Stanušić, "Stjepan pl. Hadrović (1863.-1934.) - uz 150. obljetnicu rođenja", u: Magnifikat, 14 - 2013., str. 11.

70 Nastojanje trebinjskoga klera oko izbora vlastitoga biskupa Mišić opisuje na sljedeći način: "Sekularni kler trebinjske biskupije traže (sic!) posebno za se biskupa, kandidat im (potius suus/ radije njihov) Monsig. Don Angjelo Glavinić. Kandidaturu trebinjaca podupire Excel. Dr. Stadler, ali da bi došao za biskupa 
na novoga biskupa u Mostaru, prema Mišićevu kazivanju, nastao je trostruki spor. Prvo, između nadbiskupa Stadlera i hercegovačkoga svećenstva; drugo, među brojnim kandidatima hercegovačkih franjevaca i treće, između hercegovačkih franjevaca i Zemaljske vlade s jedne strane, te raznih kandidata izvan Hercegovine (Bosanska i Dalmatinska provincija, te Vrhbosanska nadbiskupija) i njihovih zagovaratelja s druge strane. Već prilikom traženja koadjutora biskupu Buconjiću nadbiskup Stadler snažno se založio za svoga pomoćnoga biskupa dr. Šarića kao pravoga kandidata za Mostar. Kako je dr. Šarić bio manje poznat u Hercegovini, započeo je kanonik Hadrović za njega izbornu kampanju po Mostarsko-duvanjskoj biskupiji. On se osobito obraćao katoličkim laicima, nadajući se da će preko njih pridobiti i svećenstvo, franjevce i vladine predstavnike za biskupa Šarića. Danas se može dokazati da je ova akcija bila crkveno lakomislena i nezrela i da nije imala nikakva uspjeha. Mišić u svome $\check{Z} i$ votopisu i u svojoj Chronici biskupije opisuje dovoljno jasno ovu loše pripremljenu i neuspješnu izbornu utakmicu. ${ }^{71}$ Borba, natjecanje i pretjecanje za biskupsku stolicu u Mostaru poprimilo je isto tako i u Hercegovačkoj franjevačkoj provinciji često oblike samosagorijevanja. Hercegovački su franjevci bili podijeljeni najprije na starije i utjecajnije članove, koji su već godinama, čak i desetljećima, vršili najodgovornije službe u Provinciji i u Biskupiji i vidjeli su u biskupskoj stolici definitivnu krunu svoga uspješna rada u Crkvi; onda na srednju generaciju braće, koja je već djelomično participirala na crkvenoj vlasti i časti u Hercegovini te na kraju na najmlađu generaciju braće, koja je tek počela sanjati ili čak lagano težiti za crkvenom ka-

Monsig. Stjepan Hadrović, gen. vikar u Sarajevu. Ovo razumiju trebinjci pa se izvrnu proti jer nije njihov." ABO Mostar, Chronika biskupije, str. 2.

71 Vrbovanje nadbiskupa Stadlera i njegova generalnog vikara Hadrovića za biskupa Šarića po Mostaru Mišić prikazuje opširno i s određenom pobjedničkom pozom: "Nadbiskup Stadler htjeo je po svaki način za Biskupa da dojde Ivan Dr. Šarić, pomoć[ni] Biskup Stadlera u Sarajevu. Nadbiskup je slao u Hercegovinu svoje pouzdanike, da rade i izjave se u Mostaru, kako žele mjesto Buconjića ko Biskup da im dojde pres[vijetli] biskup Dr. Šarić. Emisar Nadbiskupa Stadlera za agitaciju po Hercegovini bio je prečasni Stjepan pl. Hadrović, kanonik vrhbosanski. Prečasni Hadrović držao je u Mostaru pouzdane sastanke sa vidjenijim katolicima, u stanu gosp. Ivana Šarića, gradj. poduzetnika. Ovo mi je pripovijedao sam g. Ivan Šarić." ABO Mostar, Curriculum vitae, str. 19. Na drugom mjestu opisuje kraće ali slično: "Za Mostar da postane biskup, predlaže i radi svom snagom Dr. Stadler osobu svoga pomoćnoga biskupa Dr. Šarića. Franjevci kao većina klera u biskupiji Mostar, traže kako je već rečeno, franjevca Hercegovca." ABO Mostar, Chronika biskupije, str. 2. 
rijerom u Hercegovini. Mišić, premda sam sebe prikazuje kao neutralna promatrača, ima ovdje prilično negativno mišljenje o držanju i uspješnosti taktike hercegovačkih franjevaca. ${ }^{72} \mathrm{Tu}$ treba ponajprije spomenuti starije kandidate: zaslužni i "vječiti" provincijali kao što su bili fra Nikola Šimović i tada aktualni provincijal fra Luka Begić. Zatim slijede kandidati srednje generacije: biskupijski tajnik, definitor, kulturni radnik i prosvjetitelj, provincijal i aktualni kustod fra Ambro Miletić; ${ }^{73}$ agilni gimnazijski profesor, dugogodišnji župnik, graditelj, biskupijski tajnik, definitor i član bosansko-hercegovačkoga sabora fra Dujo Ostojić; neumorni kulturni radnik, biskupijski tajnik i upravitelj biskupije in materialibus fra Radoslav Glavaš; bogoslovijski profesor i ispitivač, gimnazijski vjeroučitelj, definitor, publicist i kulturni radnik fra Špiro Šimić. Na kraju su došli u obzir i najmlađi kandidati: odgojitelj mladeži, bogoslovijski profesor u Mostaru, župnik, gvardijan, priznati publicist i narodni prosvjetitelj fra David Nevistić; meštar novaka, ravnatelj Franjevačke gimnazije na Širokom Brijegu i definitor fra Pacifik (Mirko) Matijević; dugogodišnji bogoslovijski profesor, solidni poznavatelj katoličke dogmatske teologije i višegodišnji rektor mostarske bogoslovije fra Lujo Bubalo $;^{74}$ mladi i vrlo učeni profesor crkvenoga prava na Mostarskoj bogosloviji fra Jerko Boras, ${ }^{75}$ koji je sam sebe vješto preporučivao za biskupa u Mostaru $;^{76}$ te na kraju najmlađi među njima, profesor bogoslovije u Mostaru, kasnije zasigurno jedan od najprofiliranijih hercegovačkih franjevaca, fra Leo Petrović. ${ }^{77}$ Svi ovi stariji, srednji i

72 "Čudno je da hercegovački franjevci nijesu na agitaciju Šarić Dr. Ivan za Biskupa u Mostar mjesto Buconjića da dojde, odgovorili agitacijom, hercegovački franjevac da dojde. Nerad, apatija za ovaj slučaj tko će biti Biskup iza Buconjića, teško je razumjeti. Ili je bila nesloga tko da bude ili je bio nedostatak kandidata - nerad, posvemašnja apatija neshvatljiva je. Nješto je bilo". ABO Mostar, Curriculum vitae, str. 19.

73 Fra Ambro Miletić (Dobro Selo, Brotnjo, 1857. - Nevesinje, 1923.). Usp. R. JoLIć, Leksikon hercegovačkih franjevaca, str. 265-266.

74 Fra Lujo Bubalo (Hardomilje kraj Ljubuškog, 1878. - Mostar, 1940.). Usp. R. Jolić, Leksikon hercegovačkih franjevaca, str. 78-79.

75 Fra Jerko Boras (Vitina, 1878. - Mostar, 1946.). Usp. R. Jolić, Leksikon hercegovačkih franjevaca, str. 69.

76 Borasova samopreporuka nalazi se u jednom dodvoračkom pismu upućenu apostolskom delegatu Bastienu. Usp. Ostavština apostolskoga delegata Bastiena u Bečkoj nuncijaturi.

77 Fra Leo Petrović (Klobuk, 1883. - Mostar, 1945. - ubijen). Usp. R. Jolić, Leksikon hercegovačkih franjevaca, str. 311. 
mlađi hercegovački franjevci, jer nisu znali nastupiti složno, izgubili su borbu za biskupsku stolicu u Mostaru kako kao zajednica, tako i kao pojedinci. Mišić, koji je dobro poznavao stvari u Hercegovačkoj provinciji, posebno njihovu neslogu, ${ }^{78}$ komentira više poticajno nego li pobožno: "Deus disponit (Bog određuje)! Sloga i molitva nužna je kad se biskup traži."79 Kada se nisu našli prikladni, "sgodni", kako kaže Mišić, kandidati među Hercegovcima, bio je zamoljen od Vlade, da predloži prikladna "sgodna" franjevca iz Bosne. Odmah se odazvao i predložio: fra Bonifacija Vidovića ${ }^{80}$ iz Livna, generalnoga pohoditelja u Hercegovačkoj provinciji 1910. godine, te već spomenute bosanske franjevce: fra Anđela Franića i fra Danijela dr. Bana ${ }^{81}$ Zanimljivo je da se ova imena kandidata, najvjerojatnije iz 1911. godine ne slažu s imenima Mišićevih kandidata iz veljače 1910., koje je uručio predstavniku Zemaljske vlade. Isto tako ova se imena ne nalaze ni u Arhivu BiH niti su bila predmetom razmatranja Vladinih pročelnika ili savjetnika. Ove retke u Chronici biskupije pisao je Mišić 1912./1913. godine i mogao se još točno sjetiti svih detalja. Najvjerojatnije, u svojoj "očinskoj pažnji", nadodao je koji pium mendacium za svoju subraću u Bosni, da im pokaže kako se on i u posljednjem trenutku borio da bi jedan od njih došao za biskupa u Mostaru, a ne on osobno. Ostavlja dojam da njemu nije bilo tako važno tko će od njih trojice postati biskup, ali svakako je trebao postati jedan predstavnik iz jednoga od tri vrlo važna i ugledna samostana: Gorica, Fojnica i Kreševo.

\subsection{Teško usuglašavanje između Sarajeva, Beča i Rima}

Neusuglašenost između Zemaljske vlade $s$ jedne, te hercegovačkih franjevaca i raznih kandidata izvan Provincije i njihovih zagovarača s druge strane, ostavila je traga u Hercegovini i u Mišićevim spisima. Ovom sporu i neusuglašenosti pridonio je još za svoga života biskup

78 [Hercegovački franjevci] "Neslažu se u kandidatima. Puno kandidata. Jedni hoće o. Glavaša Radoslava, mali broj; drugi o. Luju Bubala; mislilo se i na o. Leona Dr. Petrovića, na o. Luku Begića, ... jedni za o. Davida Nevistića etc. etc. Bilo ih je još. Da sam ja došao u Banjaluku, mjesto mene jedan Hercegovac u Mostar, to bi bila moja želja." ABO Mostar, Chronika biskupije, str. 2.

79 Isto.

80 Fra Bonifacije Vidović (Dobro kraj Vidoša, 1870. - Gorica kraj Livna, 1952.). Usp. A. S. Kovačić, HFBL, str. 558.

81 ABO Mostar, Curriculum vitae, str. 19. 
Buconjić, koji se očito više zalagao za kandidata sa strane nego za nekoga hercegovačkog franjevca. Navodno je imao u tome veliku podršku u Vladinu savjetniku Antoniju Vukoviću, rođenom Dalmatincu, koji je podupirao Buconjićeva kandidata fra Franu Lulića, misli Mišić. ${ }^{82}$ Lulićeva kandidatura, premda ju je podržavala Sveta Stolica, potrajala je u Sarajevu samo kratko vrijeme, jer nju Zemaljska vlada poslije Buconjićeve smrti nije više uzimala ozbiljno. Uostalom Lulić je uz nekoliko druge dalmatinske subraće bio kandidat za nadbiskupa u Baru, u Crnoj Gori, bez sumnje vrlo prestižno mjesto, ali gotovo bez katoličkih vjernika. ${ }^{83}$ No, i on je mogao kalkulirati poput Mišića: Osigurati za Provinciju Presvetoga Otkupitelja nadbiskupiju Bar s jednim drugim dalmatinskim kandidatom i u međuvremenu dobiti Mostar za sebe i za Provinciju, kada to već želi Sveta Stolica i biskup Buconjić. I sam Mišić u svojoj skromnosti, opet u borbi za prestiž Franjevačkoga reda i njemu drage Bosne Srebrene, bio je predviđen za barskoga nadbiskupa, kako sam piše. ${ }^{84}$

Cijelo ovo vrijeme u Rimu su strpljivo čekali na veoma poželjnu promjenu stajališta u Ministarstvu u Beču i u Zemaljskoj vladi u Sarajevu. Kako Sveta Stolica nije prihvaćala provincijala Mišića, počela je tražiti druga imena i nove mogućnosti za biskupa u Mostaru, što nam svjedoči 22. svibnja 1911. novi austro-ugarski veleposlanik pri Svetoj Stolici princ Schönburg-Hartenstein. ${ }^{85} \mathrm{U}$ svom dopisu prenosi mišljenje kardinala Merry del Vala, državnoga tajnika Svete Stolice, koji u eventualnom Mišićevu imenovanju vidi dvije poteškoće. Či-

82 "...ozbiljno dalmatinac Vuković, uplivan kod Vlade, radije za o. Franu Lulića, generalnoga definitora franjevaca u Rimu, rodom dalmatinca..."

83 ABO Mostar, Curriculum vitae, str. 19.

84 "Umro je presvijetli gosp. fra Šimo Milinović, Nadbiskup Bara. Propaganda u Rimu tražila je od generala franjevačkoga reda, neka jednoga sgodnoga franjevca predloži za Nadbiskupa u Bar. General reda preč. Schüler (sic!) Dionis htjeo je mene." Isto, str. 19.

85 Johann princ Schönburg-Hartenstein (1864. - 1937.), bio je austro-ugarski veleposlanik pri Svetoj Stolici 1911. - 1918. Po osobnom uvjerenju bio je uvjereni katolik, dok je politički bio više naklonjen austrijskim interesima Dvojne Monarhije, za razliku od grofa Szécsena, koji je posvuda zastupao ugarske i posebno protuhrvatske ciljeve. Djelovanje princa Schönburg-Hartensteina bilo je u doba teška i očita raspadanja Dvojne Monarhije. Usp. A. HudAL, Die österreichische Vatikanbotschaft, str. 274-314; F. ENGEL-JANOssI, Österreich und der Vatikan 1846-1918., II., str. 126-130; P. VRAnkić, Religion und Politik, str. 517. 
njenica je da je Mišić kao franjevac predstavljao u očima nadbiskupa i metropolita Stadlera prvu i pravu poteškoću. Drugu poteškoću predstavljala je činjenica da je Mišić, zbog svojih političkih stajališta, postao Stadleru osoba nesimpatična, persona non grata, što je moglo dovesti do sukoba među biskupima u metropoliji. ${ }^{86}$ Stoga, razmišljao je da kardinal državni tajnik, ako se želi da izbor jednoga franjevca bude prihvatljiv nadbiskupu Stadleru, ne treba predlagati upravo jednoga, koji je nadbiskupu još odbojan. Stoga mu se činilo nesvrhovito (unzweckmäßig) inzistirati na izboru provincijala Mišića za biskupa u Mostaru, kao uostalom i na pojedinim franjevcima u $\mathrm{BiH}$, vjerojatno je mislio na one u Hercegovini, jer je kao Bosanac, premalo bio prikladan za Hercegovinu. Tom prigodom upozorio je Merry del Val veleposlanika princa Schönburg-Hartensteina da mu je bio spomenut još jedan ili drugi kandidat, čijih se imena trenutačno nije mogao sjetiti, i da oni ne stvaraju spomenute poteškoće te da su prikladni za biskupsku službu u Mostaru. ${ }^{87}$ Veleposlanik Dvojne Monarhije princ Schönburg-Hartenstein došao je do zaključka da Sveta Stolica ne prihvaća provincijala Mišića kao biskupskoga kandidata u Mostaru i predložio je da treba pričekati ishod apostolskoga pohoda benediktinca Bastiena ${ }^{88}$ u Bosni, argumentirajući da će za Svetu Stolicu biti

86 Kardinal državni tajnik Merry del Val predviđao je vrlo dobro. Kada je Zemaljska vlada u ljeto 1913. godine odlučila prisiliti nadbiskupa Stadlera na odstupanje ili na prisilno uklanjanje s nadbiskupske stolice u Sarajevu od cara Franje Josipa ili od pape Pija X., pripremala je izravno mostarskoga biskupa Mišića za njegova nasljednika u Sarajevu. Biskup Mišić je u zavjeri Vlade objeručke prihvatio ovu, u odnosu na svoga metropolita, nekolegijalnu ulogu. Usp. P. VRAnkić, Religion und Politik, str. 730-734.

87 Prijepis izvješća austro-ugarskoga veleposlanika princa Schönburg-Hartensteina, od 22. svibnja 1911. ABH Sarajevo, GFM Präs. BH, 741/1911; P. VRANKIĆ, Religion und Politik, str. 516-517.

88 Dom Pierre Bastien (1866. - 1940.), belgijski benediktinac iz opatije Maredsous u Ardenima, bio je ugledan crkveni pravnik i profesor na tadašnjoj Benediktinskoj visokoj školi Sveti Anzelmo u Rimu. Od prosinca 1910. do listopada 1914. Bastien je bio apostolski delegat i pohoditelj u BiH. Brzo se poistovjetio sa zahtjevima Vlade u Sarajevu i željama franjevaca u Bosni. Svojim negativnim izvješćima o nadbiskupu Stadleru, Vrhbosanskom kaptolu, te žalosnom financijskom stanju Vrhbosanske nadbiskupije, doveo je nadbiskupa Stadlera u vrlo neugodan položaj. Na zahtjev Vlade u Sarajevu Stadler je trebao biti svrgnut s nadbiskupske stolice odreknućem. Car Franjo Josip i sveti papa Pio X. spriječili su ovu međunarodnu spletku protiv Stadlera i nisu zatražili njegovu demisiju, premda je kardinal državni tajnik Merry del Val tražio njegovu ostavku. Austrijski povjesničar, inače vrlo dobar poznavatelj povijesti Crkve u 
odlučujući sadržaj izvješća apostolskoga pohoda. ${ }^{89} \mathrm{No}$, prije nego što je delegat Bastien mogao obaviti svoj pohod i poslati izvješće u Rim, dao se na posao Nikola Mandić, ${ }^{90}$ predsjednik Bosansko-hercegovačkoga sabora, koji je bio razborita mišljenja da Mostar treba jednoga umjerenijeg biskupskoga kandidata, nego što je bio Mišić, po mogućnosti hercegovačkoga franjevca. Stoga on predloži Vladi u Sarajevu dvojicu hercegovačkih i jednoga bosanskog franjevaca: 1. fra Ambru Miletića, prijašnjega provincijala i virilnoga člana Bosansko-hercegovačkoga sabora u proljeće 1910., preporoditelja i prosvjetitelja u Hercegovini; 2. fra Davida Nevistića, župnika u Šuici, profesora bogoslovije, pučkoga preporoditelja i hrvatski orijentirana redovnika; 3 . bosanskoga franjevca fra Anđela Franjića, gimnazijskoga profesora i ravnatelja te aktualnoga gvardijana u Fojnici. Ova lista kandidata dr. Mandića, koji su imali jasnu hrvatsku orijentaciju, isto tako nije bila po volji Vlade. Lista je bila brzo "pročešljana" od dvorskoga savjetnika Otta Paula, ${ }^{91}$ koji je odbacio svu trojicu kandidata zbog njihovih

ovom razdoblju Monarhije, Engel-Janosi preuzeo je kao činjenicu ovo nekritično držanje austro-ugarske politike u $\mathrm{BiH}$ kao i držanje delegata Bastiena. Usp. F. Engel-Janosi, Österreich und der Vatikan, II., str. 119-121; P. VRANKIĆ, Religion und Politik, str. 713-734.

89 "daß es daher auch diesbezüglich zweckmäßig sein dürfte, dessen [Bastiens] Rückkehr von der Visitationsreise abzuwarten." ABH Sarajevo, GFM Präs. BH, 741/1911; P. VRankić, Religion und Politik, str. 517.

90 Nikola Mandić (Travnik, 1869. - Zagreb, 1945.), ugledan hrvatski odvjetnik u Sarajevu, suutemeljitelj 1907. godine Hrvatske narodne zajednice u $\mathrm{BiH}$, kasnije i njezin predsjednik. Bio je član Bosansko-hercegovačkoga zemaljskog sabora 1910., a njegov predsjednik 1911., donačelnik grada Sarajeva, a od godine 1914., kraljevom odlukom, zamjenik zemaljskoga poglavara $\mathrm{BiH}$. Utemeljitelj je i prvi predsjednik Hrvatske centralne banke i podružnice Poljoprivredne banke u Sarajevu. Godine 1920. izabran je za narodnoga zastupnika u Ustavotvornoj skupštini Kraljevine Srba, Hrvata i Slovenaca na listi Hrvatske težačke stranke. U Skupštini je odlučno ustao protiv Vidovdanskoga ustava i napustio Skupštinu. Premda se u NDH nije politički angažirao, bio je imenovan 2. rujna 1943. od Poglavnika predsjednikom Vlade NDH. Na tom položaju ostao je do kraja mijenjajući tri puta sastav Vlade. Poslije povlačenja u svibnju 1945. Britanci su ga uhitili i izručili vlastima komunističke Jugoslavije. Sud II. armije Jugoslavije osudio ga je na smrt u Zagrebu 6. lipnja 1945. Neposredno poslije toga bio je pogubljen. Usp. HE, 7, str. 31; P. VRANKIĆ, Religion und Politik, str. 517.

91 Otto Paul, dvorski savjetnik (Hofrat), kasnije nasljednik Georga Treščeca i pročelnik odjela za bogoštovlje i nastavu u Zemaljskoj vladi $\mathrm{BiH}$. 
negativnih karakternih crta i nedovoljna teološkog obrazovanja. ${ }^{92} \mathrm{U}$ istom dopisu daje zanimljivu primjedbu da bi dalmatinski franjevac Lulić, kao čovjek od povjerenja Rimske kurije, mogao biti od koristi Zemaljskoj vladi. Time bi Stadlerove aspiracije mogle biti prigušene (gedämpft). ${ }^{93}$

Kada se pogleda službena prepiska Zemaljske vlade s Bečom, ovaj dopis savjetnika Paula predstavlja prvi prijedlog Sarajeva Beču da se iziđe ususret željama Svete Stolice. Poslije ljetnih dopusta 1911. pitanje imenovanja biskupa u Mostaru došlo je ponovo na dnevni red Zajedničkoga ministarstva financija. Neprihvaćanje Mišića od Svete Stolice, ukočeni hercegovački provincijalizam (der starre herzegowinische Provinzialismus), koji se odlučno protivio Mišićevu dolasku u Mostar, kao i iznenadna bolest kandidata Kurije, fra Frane Lulića u Rimu, ponukali su Ministarstvo u Beču da za Mostar ipak potraži još jedno, hercegovačko, rješenje. Stoga pročelnik odjela za bogoštovlje i nastavu Ministarstva u Beču, Ludwig Thalloczy, ${ }^{94}$ preporučuje fra Luku Begića, aktualnoga provincijala u Hercegovini, koji se sam, još u proljeće 1910., vješto preporučio za biskupa u Mostaru. ${ }^{95}$ Fra Luka je 21. listopada 1911. bio navršio 70 godina života, pet dana prije nego je Thalloczyjev dopis poslan u Sarajevo. Thalloczy, realan povjesničar i marljivi službenik, opisuje Begića bez ikakva uljepšavanja i blaćenja, sine ira et studio. On zna da je navršio sedamdesetu godinu života, zna isto tako da nema neko solidnije teološko obrazovanje, jer je pohađao franjevačke samostanske škole po Italiji. No, prema Thalloczyjevu mišljenju, Begić je uživao glas lojalnosti prema Vladi, obljubljenost u puku, visok ugled među subraćom u Provinciji. Stoga, on je mislio da bi Begić mogao biti dobro prijelazno rješenje, dok se ne nađu među mlađim hercegovačkim franjevcima sposobniji kandidati. ${ }^{96}$ Zadaća Zemaljske vlade bila je upitati, na povjerljiv način,

92 Dopis dvorskoga savjetnika Paula ministru Buriánu, 16. srpnja 1911. ABH Sarajevo, GFM Präs. BH, 1072/1911; P. VRANKIĆ, Religion und Politik, str. 517.

93 "weil dadurch die Stadlerschen Aspirationen vielleicht etwas gedämpft würden". Isto.

94 Thallóczy Ludwig (Košice - Kaschau, 1857. - Beč, 1. prosinca 1916. - prilikom povratka sa sprovoda cara Franje Josipa), ugledan historičar i političar, pročelnik odjela za bogoštovlje i nastavu u Zajedničkom ministarstvu financija u mjerodavnosti Bosne i Hercegovine.

95 Vidi gore bilješku 44 i prateći tekst.

96 Dopis pročelnika Thalloczyja doglavaru Benku, 26. listopada 1911. ABH Sarajevo, GFM Präs. BH, 1468/1911; P. VRankić, Religion und Politik, str. 518. 
provincijala Begića, bi li bio voljan prihvatiti poziv Vlade i preuzeti Mostarsku biskupiju. Doglavar Benko ostao je sigurno iznenađen ovim upitom i prijedlogom Ministarstva iz Beča. Do sada je vladala jednodušnost u ocjeni Zemaljske vlade u Sarajevu i Ministarstva u Beču: Jedini kandidat za biskupsku stolicu u Mostaru, koji dolazi u obzir, bio je fra Alojzije Mišić. Otkud ova jednodušnost u Vladi? Glavnu riječ u Zemaljskoj vladi BiH vodili su pročelnici odjela i njihovi savjetnici, koji su predstavljali apsolutnu većinu i bili isključivo prougarski ili hrvatsko-madžaronski orijentirani, kao i sam Benko. Svi su oni držali provincijala Mišića, kao ostrogonskoga studenta, koji 1880. nije pobjegao s ostalih 16 bosanskih bogoslova iz Ostrogona u Bosnu, odlučnoga protivnika proaustrijske i velikohrvatske linije nadbiskupa Stadlera, osobom za Vladu od velikoga povjerenja. No, kao savjesni činovnici željeli su se odmah dodvoriti svome vrhovnom poglavaru, ministru Buriánu, čiju su politiku zastupali u $\mathrm{BiH}$. Stoga, kada je novi biskup po Buriánovu i Thalloczyjevu mišljenju definitivno trebao biti Hercegovac, barun Benko tražio je kompromisno rješenje, prekrižio je Begića i predložio fra Ambru Miletića, kustoda Provincije, kojega je on već odavno dobro poznavao iz Nevesinja i Mostara. Osim toga bili su još i kućni prijatelji u mostarsko doba baruna Benka. Benko je istovremeno znao da je vodeći hrvatski političar u BiH Nikola Mandić bio isto tako za Miletića. Stoga on, odbacivši kandidaturu fra Luke Begića, predloži fra Ambru Miletića i naglasi još jedanput odlučno da njegov kandidat i dalje ostaje bosanski provincijal Mišić. ${ }^{97}$

\subsection{Vlada nameće svoga kandidata fra Alojzija Mišića}

Poslije ovoga jasnog stajališta baruna Benka, zamolio je ministar Burián, u šifriranu brzojavu, novoga zemaljskog poglavara generala Potioreka, ${ }^{98}$ da odustane od kandidature fra Luke Begića, i da se te-

97 Dopis doglavara Benka Thalloczyju od 2. studenoga 1911. ABH Sarajevo, GFM Präs. BH, 1468/1911; P. VRAnkiĆ, Religion und Politik, str. 518.

98 Oskar Potiorek (Bleiberg, Koruška, 1853. - Celovec, 1933.) austro-ugarski general i zemaljski poglavar $\mathrm{BiH}$ (1911. - 1914.). Zbog loše organizacije i nedovoljna osiguranja došlo je 28. lipnja 1914. do atentata u Sarajevu, u kojem je ubijen austro-ugarski prijestolonasljednik nadvojvoda Franz Ferdinand. Za vrijeme uprave zemljom $\mathrm{BiH}$, kao i za vrijeme rata protiv Srbije, Potierek se pokazao kao loš upravitelj i nesposoban general. Bio je skinut s dužnosti u prosincu 1914. Usp. Peter Broucek, "Oskar Potiorek", u: Österreichisches Biographisches Lexikon 1815-1950, (dalje: ÖBL), 8, Wien, 1983., str. 227. 
meljito raspita o kandidatu Miletiću. ${ }^{99}$ Nakon podrobna raspitivanja $\mathrm{i}$ interne konzultacije s pročelnicima Zemaljske vlade, te razgovora $\mathrm{s}$ provincijalom Mišićem, general Potiorek obrati se Ministarstvu 30. studenoga 1911. i podnese zahtjev za popunjenje Mostarsko-duvanjske biskupije i za upravu nad Trebinjsko-mrkanskom biskupijom. Jedini moguć i za Vladu prihvatljiv kandidat u danim okolnostima bio je provincijal fra Alojzije Mišić, koji je, unatoč poznatim poteškoćama, izbor prihvatio. ${ }^{100}$

99 ABH Sarajevo, LR Präs. BH, 5991/1911; P. VRAnkić, Religion und Politik, str. 518.

100 Isto. Na koje poteškoće misli zemaljski poglavar Potiorek nije poznato. Biskup Mišić opisuje i sam kako je, poput mlade, bio "prošen" za biskupa na tri mjesta. Po njegovu pričanju bio je kandidat za nadbiskupa u Baru, jer je to želio general Reda, fra Dionizije Schuler, za biskupa u Banjoj Luci, jer su to željeli stari biskup Marković i Vlada u Sarajevu, te u Mostaru, jer je to željela samo Vlada. Ovdje donosimo kratak isječak iz njegova samoopravdavajućega prikaza kandidatura za Bar, Banju Luku i Mostar: "Meni to što moja kandidatura nije se ostvarila da dojdem u Bar nije bilo žao ni teško, jer biskup Marković o. Marijan želio je svakako i tražio da ga ja zamijenim u Banjaluci ko Biskup. On je htjeo povući se u samostan. Ovaj predlog presvijetloga Markovića usvojila je i Vlada, tako sam ja bio kandidat za Banjaluku. Trebalo je, već je vrijeme da se imenuje Biskup za Mostar. Kako sam izneo, radilo se ozbiljno Šarić Dr. Ivan da dojde u Mostar, franjevci u Hercegovini, reko sam, izgubili se, šta li, iza duga vremena pozove me poglavar zemlje sebi i pita bih li ja htjeo u Mostar? Mislim, otišo bih i nebih. Ako nehodem, izgubi se Mostar za franjevce; ako odem izgubih ja za se Banjaluku. Banjaluku volim nego Mostar. Poznam biskupiju Banjaluku. Radio sam i djelovo uz presvijetloga Markovića Biskupa 14 godina. Sve mi poznato. Mostar i prilike nepoznate. Doći u nepoznato, a uz to mislit će njeko, nametnut - pa nevolja. Za Banjaluku sam sebi siguran. Traži me Biskup, hoće Vlada. Ko pokus u zadnji čas iznešen je mladi franjevac Hercegovac o. Lujo Bubalo, nebili on mogao postati Biskup. Sve se kušalo, nije išlo. Na koncu da se spasi što se dade spasiti, na nagovor Poglavara g. Oskara Potioreka primio sam kandidaturu. Tako iza trogodišnje vakancije došlo je do imenovanja, 12. februara 1912. postao sam mostarski biskup." ABO Mostar, Curriculum vitae, str. 19. Ovdje je nužno kratko komentirati ovaj nejasan i na više mjesta netočan prikaz biskupa Mišića u šest točaka: 1 . Sveti Zbor za raširenije vjere (Kongregacija Propagande) u Rimu ne spominje Mišića kao kandidata za nadbiskupa u Baru. Za nju su prvi kandidati sinjski franjevci, koji su Bar smatrali svojinom i na drugom mjestu članovi domaćega svjetovnoga klera. 2. Iz Mišićeva Životopisa, koji je nastao 1941./1942., vidi se dobro da on nije bio najbolje informiran, ili se tih posljednjih godina svoga života nije više mogao točno prisjetiti što je sve Vlada u Sarajevu pred njim i iza njegovih leđa radila, poduzimala i dogovarala, premda je on bio prvi čovjek njezina povjerenja u Katoličkoj Crkvi u BiH. 3. Zadnji kandidat među hercegovačkim franjevcima, po izvorima Arhiva u Beču i u Sarajevu, nije bio fra Lujo Bubalo, kako tvrdi 
Nakon što je Zemaljska vlada donijela definitivnu odluku i uputila zamolbu na Zajedničko ministarstvo, pokrenuta je u Beču moćna diplomatska mašinerija Monarhije. Ministar Burián preporuči 5. siječnja 1912. ministru vanjskih poslova Aehrenthalu odluku Zemaljske vlade i Mišićevu kandidaturu za mostarskoga biskupa, te ga zamoli da instruira veleposlanika Dvojne Monarhije pri Svetoj Stolici, kako bi pridobio Papinu suglasnost za Mišićevo imenovanje. ${ }^{101} \mathrm{U}$ dopisu veleposlanika, princa Schönburg-Hartensteina, koji je dan na uvid ministru Buriánu, Sveta Stolica, tj. kardinal državni tajnik, Merry del Val, zadržala je i dalje svoje negativno i suzdržano mišljenje o provincijalu fra Alojziju Mišiću. ${ }^{102}$ Koje su to stvari, akti, moralne, odnosno karakterne crte, ili politički potezi kod Mišića tako snažno iritirali Svetu Stolicu da je toliko dugo odbijala njegovo imenovanje, nije poznato, ali se preko analogije drugih slučajeva dadu naslutiti. U gotovo svim ovakvim i sličnim slučajevima, pojavljivali su se najljući protivnici i najnečasnije stvari iznosili su obično uvijek izravni konkurenti za biskupsku stolicu. Mišić je imao brojne protivnike, kako među franjevcima Bosne Srebrene, tako i među hercegovačkim i dalmatinskim franjevcima. Loše vijesti za Mišića, kako se Vlada stalno pribojavala, nisu morale stizati samo iz okruženja nadbiskupa Stadlera i njegova kaptola, nego i od hrvatskoga političara Nikole Mandića, koji je bio najbolji poznavatelj katoličke i hrvatske scene u Sarajevu i u cijeloj $\mathrm{BiH}$, te je osobno radije htio vidjeti kao biskupa u Mostaru fra Ambru Miletića. I na kraju ne smije se isključiti i uloga generalnoga definitora, fra Frane Lulića, u Rimu utjecajna hrvatskog franjevca i kandidata za Mostarsku biskupiju po želji biskupa Buconjića i Državnoga tajništva Svete Stolice. Budući da je fra Frano bio ozbiljno obolio, Sveta Stolica nije imala više nijednoga drugoga kandidata kojega bi Vlada u Sarajevu prihvatila, te je odlučila popustiti

Mišić, nego fra Ambro Miletić. 4. Ni datum svoga biskupskoga imenovanja ne pogađa više biskup Mišić. Na podnesku ili zamolbi ministra Buriána od 7. veljače 1912., kako je tada bilo u praksi Carske kancelarije, stoji da je car Franjo Josip 14. veljače 1912. odobrio i imenovao fra Alojzija Mišića biskupom u Mostaru. 5. Mišić je bio imenovan 14. veljače 1912. biskupom, ali on to još nije bio postao. Tek biskupskim posvećenjem 18. lipnja 1912. i intronizacijom 14. srpnja 1912. u Mostaru Mišić je postao stvarno mostarski biskup. 6. Točniji prikaz posljednjega susreta u Zemaljskoj vladi donosi Mišić u svojoj Chronici biskupije. Usp. ABO Mostar, Chronika biskupije, str. 1-2.

101 Dopis ministra Buriána ministru Aehrenthalu od 5. siječnja 1912. ABH Sarajevo, GFM Präs. BH, 1635/1911; P. VRANkić, Religion und Politik, str. 518.

102 Isto. 
i protiv osobnoga uvjerenja prihvatiti kandidata Vlade, fra Alojzija Mišića. Čim je početkom veljače ipak stigla brzojavom vijest iz Rima da je papa Pio X. prihvatio kandidaturu Mišića, ministar Burián podnio je molbu i obrazloženje caru Franji Josipu za imenovanje provincijala Mišića biskupom u Mostaru. ${ }^{103}$ Car je, u skladu s Konvencijom između Svete Stolice i Austro-Ugarske, od 8. lipnja 1881., i uz pristanak Svetoga Oca (vi conventionis cum Sancta Sede Apostolica ac Beatissimi Patris consensu) udovoljio molbi svoga ministra i 14 . veljače 1912. imenovao Mišića biskupom u Mostaru. ${ }^{104}$ To je brzojavom priopćio Vladi, tek 20. veljače 1912., od Cara novoimenovani zajednički ministar financija, Leon Biliński. ${ }^{105}$ Nije poznato kako je nadbiskup Stadler osobno reagirao na ovo imenovanje, no ipak se kasnije oglasio brzojavom kratko, korektno i molitveno: "Čestitam Vam srdačno k novoj časti. Dao Gospodin da budete secundum cor suum. Stadler."106

Poslije carskoga imenovanja, po ustaljenoj praksi, bilo je potrebno i papinsko svečano proglašenje (prekonizacija), kojoj je prvo morao prethoditi obavijesni proces. Taj je proces obavljen u Bečkoj nuncijaturi pred msgr. Rossijem, tadašnjim otpravnikom poslova nunci-

103 Molba ministra Buriána, upućena caru Franji Josipu, 7. veljače 1912. ABH Sarajevo, GFM Präs. BH, 189/1912. U ovoj omotnici nalaze se i drugi dokumenti glede imenovanja biskupa Mišića. Vidi još: ASV SS 1912, rub. 247, fasc. 3, n. 56.155, fol. 15. Carski dekret imenovanja, koji je naknadno izdan, nosi datum 11. ožujka 1912.

104 Brzojav ministra Leona Bilińskog provincijalu Mišiću 5. ožujka 1912., ABH Sarajevo, GFM Präs. BH, 365; P. VRankić, Religion und Politik, str. 519. U hrvatskoj historiografiji ušuljala se pogrješka, danas općenito prihvaćena kao "sacrosancta veritas", da je car Franjo Josip imenovao Mišića biskupom u Mostaru 12. veljače 1912. Ovoj pogrješci kumovao je i sam Mišić, koji u Chronici biskupije piše točno 14. veljače 1912., u Životopisu pogrješno navodi 12. veljače kao dan svoga biskupskog imenovanja. ABO Mostar, Chronika biskupije, str. 3; Isto, Curriculum vitae, str. 19; usp. Krunoslav Draganović, Opći šematizam Katoličke crkve u Jugoslaviji, Sarajevo, 1939., str. 169. Danas tu pogrješnu tvrdnju preuzimaju i vrlo učeni povjesničari i misle da je papa imenovao Mišića biskupom 12. veljače 1912. Usp. T. Vukšıć, "Mostarski biskup Alojzije Mišić (1912.-1942.) za vrijeme Drugog svjetskog rata", (I.), str. 223.

105 Leon Biliński (Zaleszczyki u Galiciji, danas Ukrajina, 15. lipnja 1846. - Beč, 14. lipnja 1923.), austrijsko-poljski političar, dvaput austrijski ministar financija (1895. - 1897.) i (1909. - 1911.) te zajednički ministar financija AustroUgarske i upravitelj Bosne i Hercegovine (1912. - 1915.). Usp. "Leon Biliński", u: ÖBL, I., Wien, 1957., str. 84-85.

106 ABO Mostar, Brzojav nadbiskupa Stadlera 1912. 
jature. Obavijesnom procesu nazočili su kao svjedoci fra Marijan Jakovljević, koji je dopratio Mišića iz Bosne i fra Julijan Smerček, minoritski gvardijan u Beču. ${ }^{107}$ Tek kada su dokumenti obavijesnoga procesa iz Beča stigli u Rim, moglo je uslijediti svečano papinsko proglašenje na sjednici kardinalskoga zbora/konzistorija, da je carsko imenovanje dotičnoga biskupa dobro i hvale vrijedno. Papa Pio X. prekonizirao je Mišića 29. travnja $1912 .{ }^{108}$ Sljedeći korak bila je konsekracija, biskupsko ređenje u Rimu. No, prije toga morao se odreći službe provincijala Bosne Srebrene. Na provincijskom kapitulu Provincije, u Jajcu u svibnju 1912., odrekao se službe provincijala u korist novoizabranoga i uglednoga franjevca fra Lovre Mihačevića. ${ }^{109}$

\subsection{Od prekonizacije do instalacije}

Poslije svečane proklamacije njegova imenovanja u Rimu od pape Pija X. slijedilo je biskupsko ređenje (konsekracija), koju je Mišić planirao za 18. lipnja 1912. u Rimu. Na putu u Rim pratio ga je bosanski subrat iz Vareša, fra Josip Andrić, rimski student. Hercegovački redodržavnik i najozbiljniji konkurent, fra Luka Begić, poslao je na posvetu u Rim svoga kustoda i drugoga Mišićeva konkurenta, fra Ambru Miletića, "na ime franjevaca i biskupije Mostar" kako piše Mišić. ${ }^{110}$ Posveta je pripremljena u crkvi sv. Ante, u sklopu zavoda i tadašnjega učilišta Antonianum na Via Merulana u Rimu. Posvetitelj je bio franjevački kardinal i papinski diplomat Diomede Falconio (1842. - 1917.). Na posveti i poslije na upriličenom primanju u zavodu Antonianumu bili su nazočni, među ostalima, novi franjevački general Reda Pacifico Monza, austro-ugarski veleposlanik princ Schönburg-Hartenstein, te brojni predstavnici papinskih zavoda u Rimu. ${ }^{111}$ Novoposvećeni biskup Mišić bio je primljen 20. lipnja u audijenciju kod pape Pija X. Sveti Otac ga je lijepo primio, raspitivao se o njegovoj biskupiji, hvalio cara Franju Josipa i njegovu zemlju, crnogorskoga kralja Nikolu Petrovića, tasta talijanskoga kralja Viktora Emanuela, oca lijepe talijanske kraljice (J)Elene, koji je malo prije

107 ABO Mostar, Curriculum vitae, str. 19.

108 ABH Sarajevo, GFM Präs. BH, 943/1912; Hierarchia Catholica, IX. (19031922), str. 239.

109 ABO Mostar, Chronika biskupije, str. 3.

110 ABO Mostar, Curriculum vitae, str. 19.

111 ABO Mostar, Chronika biskupije, str. 3-4. 
Petar Vrankić - Izbori i imenovanja biskupâ u Hercegovini...

toga bio u Rimu i pred papom se naveliko hvalio kao zaštitnik "crnogorskih katolika". ${ }^{112}$

Na dan audijencije kod pape, 20. lipnja 1910., umro je biskup Marković u Banjoj Luci, veliki zagovornik fra Alojzija Mišića. Mišić je dobro znao što će se dogoditi u Banjoj Luci, ne bude li intervenirao. Naime, metropolit Stadler imao je pravo imenovati vikara in spiritualibus et in materialibus. Taj vikar je imao važnu ulogu do imenovanja novoga biskupa. Stoga je Mišić poduzeo sve da iz Rima uspješno preteče svoga velikoga neistomišljenika Stadlera. Naime, uspio je isposlovati, najvjerojatnije preko Generala Reda, da upravitelj in spiritualibus upražnjene Banjolučke biskupije, poslije smrti biskupa Markovića, bude imenovan fra Jozo Garić, njegov subrat, a ne Stadlerov kandidat i dijecezanski svećenik dr. Pavao Pajić. Kad je Stadler došao na sprovod u Banju Luku našao je pred sobom novoga vikara u duhovnim stvarima i budućega biskupa Garića. ${ }^{113}$ Možemo si predočiti kako se nadbiskup Stadler tada mogao osjećati u Banjoj Luci!

Iz audijencije kod Pape Mišić je ponio pozdrave caru Franji Josipu u Beč. U Beču ga je čekala audijencija i zakletva vjernosti pred Carem, koju su polagali svi biskupi Dvojne Monarhije. U audijenciju je primljen 25. lipnja i položio zakletvu. U otvorenom i prijateljskom razgovoru, kako piše, Car se raspitivao za Bosnu i za katoličku stvar. ${ }^{114}$ Isti je dan navodno krenuo iz Beča vlakom za Sarajevo i sljedeći dan, 26. lipnja, stigao u Sarajevo. Na drugom mjestu kaže da je putovao preko Pešte, što je razumljivo, jer je i tamo imao prijatelja i poznanika. No, u tom slučaju, nije nikako mogao stići u Sarajevo 26. lipnja.

Sljedeći važan korak, bez sumnje, bile su pripreme za ustoličenje i preuzimanje uprave biskupije. To su mu najvjerojatnije bili najteži koraci i trenutci u životu. Ako prije možda nije znao što znači biti nametnut protiv volje svoga budućeg svećenstva, morao je to osjetiti pri

112 Isto, str. 4.

113 "Kad je Nadbiskup Stadler došo u Banjaluku na sprovod pokj. Markovića, htjeo je da imenuje ko Metropolita vicarium in spiritualibus za Biskupiju Banjalučku. Koga? Neznam. Valjda bi bio došao Dr. Pajić Pavle, katehet, u tu kombinaciju. Rim je pako 22. VI. 1912. direktno naimenovao vicarium in spiritualibus o. Jozu Garić." ABO Mostar, Curriculum vitae, str. 19.

114 Mišić opisuje: "U audijenciji u Beču car Frano Josip primio me je vrlo ljubezno. Pozna prilike Bosne. Imao je srce za katol. stvar. Meni veli, žalim da nije veći broj katolika. Bestens wäre wenn alle kathol. Glaubens wären." ABO Mostar, Curriculum vitae, str. 19. 
dolasku u biskupiju Mostar. Kao novi biskup pozvao je na instalaciju sve "dvorjanike" Redodržave Bosne Srebrene, koje je imao oko sebe kao bivši redodržavnik: novoga redodržavnika Mihačevića zajedno s njegovim definitorima, gvardijane brojnih bosanskih samostana, kolege iz gimnazije u Visokom, uglednije župnike. K tomu su bili pozvani pročelnici Zemaljske vlade, vrhbosanski kanonici, brojni članovi Bosansko-hercegovačkoga sabora, predstavnici austro-ugarske vojske i njihove vojne glazbe, mostarski uglednici, hercegovački redodržavnik s njegovim "dvorom", dvojica privremenih upravitelja in spiritualibus i jedan in materialibus, dvojica iz Mostara i jedan iz Banje Luke. Na putu za Mostar svratio se u prvu župu Mostarske biskupije, u Konjic. Župnik fra Blaž Jerković (1880. - 1960.) nije se uopće trudio da ga ljubazno primi. Mišić piše doslovce: "Tovremeni župnik ondi bio je o. Blaž Jerković. Doček novoga biskupa bio hladan. Župnik sa njekoliko župljana. Kratak pozdrav i odzdrav pa hajd dalje."115 Drugom prigodom pitao ga je isti župnik Jerković: "koliko godina živjeli su moji roditelji. Nije dobro sve spominjati. Bolje zaboravljati". ${ }^{116}$ I u Mostaru je prijem bio vrlo hladan. Mostarski gvardijan fra Ćiril Ivanković (1878. - 1945.) nije se uopće trudio da gostoljubivo primi, posluži i "konak" ponudi brojnoj braći iz Bosne Srebrene, koji su pratili njihova prijašnjega provincijala. Na samo ustoličenje došli su, među ostalim: u ime Vrhbosanske nadbiskupije i Vrhbosanskoga kaptola pomoćni biskup dr. Ivan Šarić i kanonik Košćak, u ime Bosne Srebrene redodržavnik Mihačević sa svojim brojnim "dvorjanima", u ime Zemaljske vlade Adalbert Shek, pročelnik pravnoga odjela, dr. Mandić, predsjednik Sabora sa sabornicima dr. Sunarićem i dr. Mazzijem, isusovci, pater Ljudevit Dostal iz Sarajeva i pater Max Horrmann iz Travnika, upravitelji biskupija in spiritualibus, don Lazar Lazarević i fra Jozo Garić, hercegovački redodržavnik Begić s još dvojicom subraće, vojni zapovjednici i generali Olbert i Wuchener, okružni pročelnik Marzell, mostarski gradonačelnik Mujaga Komadina, dogradonačelnik Nikola Smoljan i muftija Abdullah Riđanović. Nedostajao je zahumsko-hercegovački episkop Petar Zimonjić, jer je bio izvan Mostara. No, bili su nazočni predstavnici pravoslavne općine i konzistorija. Predstavnici Židovske zajednice iz Mostara, ukoliko su uopće bili pozvani, nisu bili prisutni. Na instalaciji nisu bili viđeni: upravitelj biskupije in materialibus fra Radoslav Glavaš,

115 ABO Mostar, Chronika biskupije, str. 5.

116 ABO Mostar, Curriculum vitae, str. 19. 
stariji hercegovački redodržavnici: fra Nikola Šimović, fra Anđeo Nuić i fra Ambro Miletić. Na primanju u biskupskoj rezidenciji i kasnije na ručku u hotelu Neretva, pojavili su se svi prisutni gosti s ustoličenja, osim gradonačelnika Komadine i redodržavnika Begića, koji su, svaki iz svojih razloga, bojkotirali prijem. ${ }^{17}$ Dok su franjevačka glasila Bosne Srebrene vrlo pozitivno izvješćivala o ustoličenju biskupa Mišića, ${ }^{118}$ dotle su predstavnici okružne vlasti u Mostaru slali izvješća Vladi u Sarajevu o neprikladnom ponašanju pojedinih hercegovačkih franjevaca. ${ }^{119}$

Mišićev subrat i ugledan franjevac Bosne Srebrene, fra Petar Čuturić, ostavio je sljedeća svjedočanstva o nekim događajima prikazanim u ovom radu i koja ovdje donosimo: "Bivši predsjednik kolegija u Visokom, kad je postao provincijalom, znao je svojim visokim položajem i Janusovim držanjem steći važne veze i dodvoriti se velikim krugovima. Radilo se o popunjenju ispražnjene mostarske biskupske stolice. Poglavar zemlje, general Varešanin, s kojim kao komšijom bio provincijal Mišić intimus, sigurno da je na mjerodavnim mjestima preporučio ovoga za mostarsku biskupsku stolicu. Baš se Mišić trefio kod nas u Visokom - vjerojatno proračunana odsutnost iz Sarajeva - kad mu izbi žuran brzojav, dok smo zajedno iza ručka sjedili u refektoriji. U brzojavu mu se javlja, da je imenovan mostarskim biskupom. Odmah smo se pozdravili i čestitali toliko odlikovanje. Prvim osobnim vlakom, kojim je on pošao kući, svi smo ga korporativno odpratili do Sarajeva. Baš se slučilo, da prateći Mišića od stanice u samostan, sretnemo šetajućeg Stadlera, koji se pozdravi s novim kolegom i čestita mu promaknuće (?!). I na Mišiča instalaciji u Mostaru bila zastupana gimnazija i provincija po svojim predstavnicima, premda su hercegov. fratri - indignirani preferiranjem - upadno bojkotirali Mišiča dolazak za biskupa i instalaciju. No ova njihova ukočenost škodila im je u budućnosti, jer poslije fratra Mišiča dobiše za biskupa popa Petru Čulu". ${ }^{120}$

117 Isto. Redodržavnik Begić se navodno razbolio odmah nakon Mišićeva ustoličenja. ABO Mostar, Chronika biskupije, str. 5.

118 Mijo Sarajlija, "Ustoličenje biskupa Mišića", u: Serafski perivoj, 7/1912., str. 111-112.

119 Ova izvješća mogla su se 1989. godine naći u Arhivu BiH u Sarajevu, Zemaljska Vlada, instalacija biskupa Mišića.

120 Fra Leonardo Čuturić (1881. - 1947.), Autobiografija (Moja lična kronika iz sjećanja). Ljetopis Franjevačkog samostana u Fojnici. Kronika župe Brestovsko, Fojnica, 2016., str. 78. 


\section{Završne misli}

Svojim nametanjem kandidata Mišića i njegovim izborom za biskupa 1912. godine, Zemaljska vlada u Sarajevu i Ministarstvo u Beču popunili su vakantnu biskupsku stolicu u Mostaru, no nisu uspjeli pridobiti željenu naklonost domaćega klera i puka u Hercegovini, prvenstveno ne kod hercegovačkih franjevaca. Dok dijecezanski svećenici u Trebinjsko-mrkanskoj i oni malobrojni u Mostarsko-duvanjskoj biskupiji nisu mogli vidjeti nikakvu razliku između biskupa franjevca iz Hercegovine, kao što je bio Buconjić, i biskupa franjevca rodom iz Bosne, poput Mišića, dotle su hercegovački franjevci bili povrijeđeni u svome ponosu i svojim zaslugama za Crkvu i narod, jer im nije bila ponuđena i osigurana biskupska stolica u Mostaru, premda su imali dovoljno svojih sposobnih, kako mlađih, tako i starijih kandidata. Zahvaljujući svome prijateljstvu s vodećim ljudima iz Zemaljske vlade u Sarajevu, svojoj koncilijantnoj naravi, umjerenoj političkoj orijentaciji i malohrvatskoj viziji bosansko-hercegovačkoga čovjeka-katolika-Hrvata, provincijal Mišić ostavljao je vrlo pozitivan dojam na vodeće članove Vlade i bio za njih idealan kandidat. Zemaljska vlada, ostavljajući i dalje status quo u Mostaru - biskupa franjevca, nadala se preko budućega biskupa Mišića pobrati dodatne simpatije među hercegovačkim katolicima i njihovim svećenicima. Tadašnji "ugarsko-austrijski" establishment oko Zemaljske vlade u Sarajevu i Ministarstva u Beču vidio je u budućem biskupu Mišiću, za razliku od već starijega, još uvijek borbena i prema Vladinim željama i zapovijedima nepopustljiva nadbiskupa Stadlera i njegova kruga, pomirljivu, Vladi odanu i za kompromise i suradnju vrlo spremnu osobu. Ovo pozitivno mišljenje Sarajeva i Beča o provincijalu Mišiću nije dijelila Sveta Stolica, koja, gotovo pune dvije godine, nije htjela prihvatiti Mišićevo imenovanje za biskupa u Mostaru, bojeći se dodatnih sukoba u Katoličkoj Crkvi u BiH. Na kraju, u veljači 1912. papa Pio X., ne želeći se suprotstaviti caru Franji Josipu, čiju je pomoć trebao u mnogim kritičnim trenutcima za Crkvu u Dvojnoj Monarhiji i izvan nje, ipak je popustio (consensum dedit) i prihvatio Mišićevo imenovanje za biskupa u Mostaru. Imenovanje je bilo, bez sumnje, velika pobjeda politike i nastojanja Zemaljske vlade i njezinih interesa u formiranju Vladi odane i pretežno servilne crkvene hijerarhije i politike unutar Katoličke Crkve u BiH. Istovremeno, imenovanje je trebalo utvrditi i ojačati političku privrženost katoličkoga puka Dvojnoj Monarhiji, Kruni i Dinastiji. Stoga će biskup Mišić u prvoj godini svoga biskupovanja redovito ispovijedati i celebrirati vjernost Caru, Monarhiji, Dinastiji i Vladi te katoličanstvo držati državotvornim elementom 
Monarhije, kako je to on najsvečanije izjavio u siječnju 1913.: "Ja sam Vašoj preuzvišenosti uvijek iskreno otvorio se, kazao i saopćio moj plan rada za Bosnu opće, a posebno za Hercegovinu. U mene su dva ideala, Bog na nebu, Car Gospodar na zemlji. Moj rad ide onamo, za Boga i Cara, sve drugo treba ovijem dvama idealima da služi. Katolicima u Herceg-Bosni kano Confessiji nejma spasa i budućnosti bez slavne Dinastije Habsburga. Isto $\mathrm{u}$ narodnom pogledu, katolicima kano hrvatima, bez Dinastije Habsburga nejma budućnosti. Monarkija i Dinastija Habsburga isto ovako nejma pouzdana, sigurna, trajno odana elementa u Herceg-Bosni kano što su katolici."121

No, istovremeno biskup Mišić budno će pratiti politička zbivanja na jugu Europe, emocionalno, nacionalno, politički i crkveno lagano dozrijevati te se otvarati za sve prisutniju, Monarhiji oprječnu i politički maglovitu viziju: jugoslavenstvo. Tako će biskup Mišić, u godini 1912. još uvijek velika nada austro-ugarskoga političkog establishmenta u $\mathrm{BiH}$, u siječnju 1913. laudator non plus ultra Cara, Gospodara, Monarhije i Dinastije, postati u godinama 1917./1918., zajedno s većinom hrvatskih biskupa, osoba sposobna prihvatiti, u savršenoj mirnoći savjesti, raspad Monarhije, kraj Habsburške dinastije i dobrohotno pozdraviti novu državnu tvorevinu, Kraljevinu Srba, Hrvata i Slovenaca. ${ }^{122}$ Zanimljivo je, da će isti biskup Mišić 1941. godine, zajedno sa svojim subratom fra Jozom Garićem, banjolučkim biskupom, i s metropolitom Ivanom Šarićem u Sarajevu, mirno prihvatiti raspad te njemu i svima drugima 1918. drage državne tvorevine i optirati za sljedeću državno-političku opciju NDH, ovaj put s velikohrvatskim vizijama. Dok su njegov subrat i biskup fra Jozo Garić iz Banje Luke, te njegov metropolit Ivan Šarić iz Sarajeva, poslije sloma i ove prolazne velikohrvatske, (hrvatsko-muslimanske), državne tvorevine, pogrješno procijenili da moraju napustiti zemlju, Mišić je imao veliku i nezasluženu milost da nije morao donijeti ovu sudbonosnu odluku. Njegovo usnuće u ožujku 1942. godine može se mirno nazvati, "milost pravovremene smrti".

121 Zamolba biskupa Mišića, od 9. siječnja 1913. zemaljskom poglavaru, generalu Potioreku. Kriegsarchiv Wien, Nachlass Potiorek, k. 6, br. 2. Usp. HusniJA Kamberović, "Pismo mostarskog biskupa fra Alojzija Mišića upućeno zemaljskom poglavaru Oskaru Potioreku 1913. godine", u: Prilozi, 33, Sarajevo, 2004., str. 211-218. Zemaljski poglavar, general Potiorek, bio je ujesen 1912. najodlučniji pobornik Mišićeva imenovanja na biskupsku stolicu u Mostaru.

122 Božo GolužA, Katolička Crkva u Bosni i Hercegovini 1918.-1941., Mostar, 1995., str. 60-70. 
Mišićev subrat, bosanski franjevac, inače učeni fra Ignacije Gavran, piše pedeset osam godina poslije Mišićeve smrti da je "biskup svojim djelovanjem kroz trideset godina pokazao da je iskren prijatelj hercegovačke franjevačke provincije". ${ }^{123}$ Istovremeno danas, kada se čitaju Mišićeve primjedbe, sudovi i mišljenja o hercegovačkim franjevcima iz njegove Chronike biskupije, posebno iz njegova Curriculuma vitae, koji je pisao neposredno pred smrt, vidi se jasno da u tridesetogodišnjem suživotu "blažene uspomene biskupa Alojzija" s Hercegovačkom franjevačkom provincijom nije sve bilo ni uspješno, ni iskreno, ni prijateljski. Drugim riječima, erozija crkvene harmonije, svećeničke sloge i ljubavi, redovničke stege i biskupske jurisdikcije u Crkvi u Hercegovini, započeta u posljednjim godinama biskupovanja fra Paškala Buconjića, doživjela je snažan i galopirajuć uspon u tridesetogodišnjoj biskupskoj službi fra Alojzija Mišića.

123 I. Gavran, "Fra Alojzije Mišić, biskup", str. 72. 


\section{Elections and Appointments of Bishops in Herzegovina at the Time of Austro-Hungarian Rule (1878-1918) - the Case of Bishop Fr. Alojzije Misic (1912)}

\section{Summary}

In this second paper on the election of the bishops in Herzegovina at the time of Austro-Hungarian rule (1878-1918), which in some ways follows the topic discussed in the first paper, shows a very tense and resistant struggle over the election of the second bishop in Herzegovina, a Franciscan monk and Provincial Alojzije Misic. After a brief overview of the historical-legal context of the Catholic Church in Herzegovina at the time of AustroHungarian rule, the first chapter covers the situation of finding a new bishop cum iure successionis, (a coadjutor bishop with the right of succession) to assist the elderly bishop Buconjic in Mostar. The interested parties in a very close competition were: The State Government of Bosnia-Hercegovina in Sarajevo, the Joint Ministry of Finance in Vienna, Archbishop Josip Stadler as the Metropolitan Bishop of Vrhbosna, Bishop Buconjić in Mostar, the Provincial of Bosnian Franciscan Province (Bosna Srebrena) - Fr Alojzije Misic and the Provincial of the Franciscan Province of Herzegovina - Fr. Luka Begić as well as the Holy See in Rome (Vatican). This competition, which turned into a real struggle, including even the disparaging of opponents in $\mathrm{BiH}$, Vienna and Rome, lasted from the end of January to the beginning of December 1910. As the Holy See in Rome was not convinced of the suitability of the only candidate who was supported by the State Government in Sarajevo - Provincial Misic, his appointment was suspended until the Bishop Buconjic's death on December $8,1910$.

The Bishop Buconjic's death was followed by the second round of the competition, described in the third chapter of this paper, in which, apart from the old ones, some new actors and candidates took part. First of all, Archbishop Stadler appeared as a metropolitan and appointed temporary administrators in spiritualibus (in spiritual matters) and in materialibus (in the material goods) of the diocese of Mostar-Duvno. This ensured the minimum functioning of dioceses. After that his candidate list the State 
Government, as well as to the Holy See. Stadler's list of candidates could not be accepted by the Government because he had, for years, publicly criticized the State Government and their actions against him, his institutions, the priests and the Catholic Church in $\mathrm{BiH}$ in general. In Rome, Stadler's candidates were looked at with certain understanding and sympathy, especially the auxiliary bishop Dr. Ivan Saric. But the State Government further supported its candidate, the Bosnian Provincial Misic, not only as a suitable man of the Church, but also as a man of their trust, and a house friend of some Government officials. Therefore, the Government offered some ridiculous and non-objective arguments when it came to the candidates who it did not favour or who were not the right competition for Misic. Among the candidates was Fr. Frano Lulic from Makarska, who was strongly supported by Rome and Bishop Buconjic. Being a Croat from Dalmatia, he was presented as inappropriate because he could not understand the mentality of the people in Herzegovina, although he was born in a place three times closer to Herzegovina than the Provincial Misic's birthplace. This is how the Government's policy manifested as merum absurdum in se!

Freshness in hard-bargaining talks, based on the political and personal beliefs, was brought by the President of the BosnianHerzegovinian Parliament, Dr. Nikola Mandic, who was not convinced enough of the suitability of Provincial Misic and demanded the appointment of one of the Herzegovinian Franciscans, an idea accepted even by the Ministry in Vienna. Although the Government of Sarajevo tried not to contradict the Ministry in Vienna and partially accepted its proposals, it remained deeply convinced of the correctness of its position: Provincial Misic was the only suitable candidate. Since the State Government believed that Misic was the only suitable candidate for the bishop in Mostar, at the same time, the Holy See, by the beginning of February 1912, considered Misic as highly unsuitable for this position. With the news that candidate Lulic was seriously ill, and when the dispute over the bishop's appointment in Mostar could lead to political tension between Vienna and the Holy See, the State Secretariat of Holy See and Pope Pius X himself decided to accept Fr. Alojzije Misic's candidacy in early February 1912, thus paving the way for his appointment as Bishop of Mostar.

This research is based on archival sources. The ambiguity, sometimes real contradictions with the names of the candidates, the course of negotiations and absence of commendable words about the Franciscan Friars, were found in the Chronicles of the 
Petar Vrankić - Izbori i imenovanja biskupâ u Hercegovini...

Diocese and the Autobiography, written post factum by Bishop Misic, preserved in the Diocesan Archives of Diocese MostarDuvno in Mostar.

Keywords: Herzegovina; Diocese of Mostar-Duvno; Diocese of Trebinje-Mrkan; State Government of Bosnia-Hercegovina; Joint Ministry of Finance; Austria-Hungary; Bosnian Franciscans; Herzegovinian Franciscans; Bishop Paskal Buconjic; Provincial Alojzije Misic; Fr. Frano Lulic; Archbishop Stadler; Dom Pierre Bastien. 